\title{
‡USGS
}

\section{Methods and Preliminary Results of Heavy- Mineral Studies in Liberia}

\author{
by Sam Rosenblum ${ }^{1}$ and G.W. Leo* U.S. \\ Geological Survey and S.P. Srivastava* Liberian \\ Geological Survey
}

\section{Open-File Report 00-259}

\section{0}

This report is preliminary and has not been reviewed for conformity with U.S Geological Survey editorial standards or with the North American Stratigraphic Code. Any use of trade, firm, or product names is for descriptive purposes only and does not imply endorsement by the U.S. Government.

U.S. Department of the Interior

\section{U.S. Geological Survey}

${ }^{1}$ Denver, Colorado

*Deceased 


\section{CONTENTS}

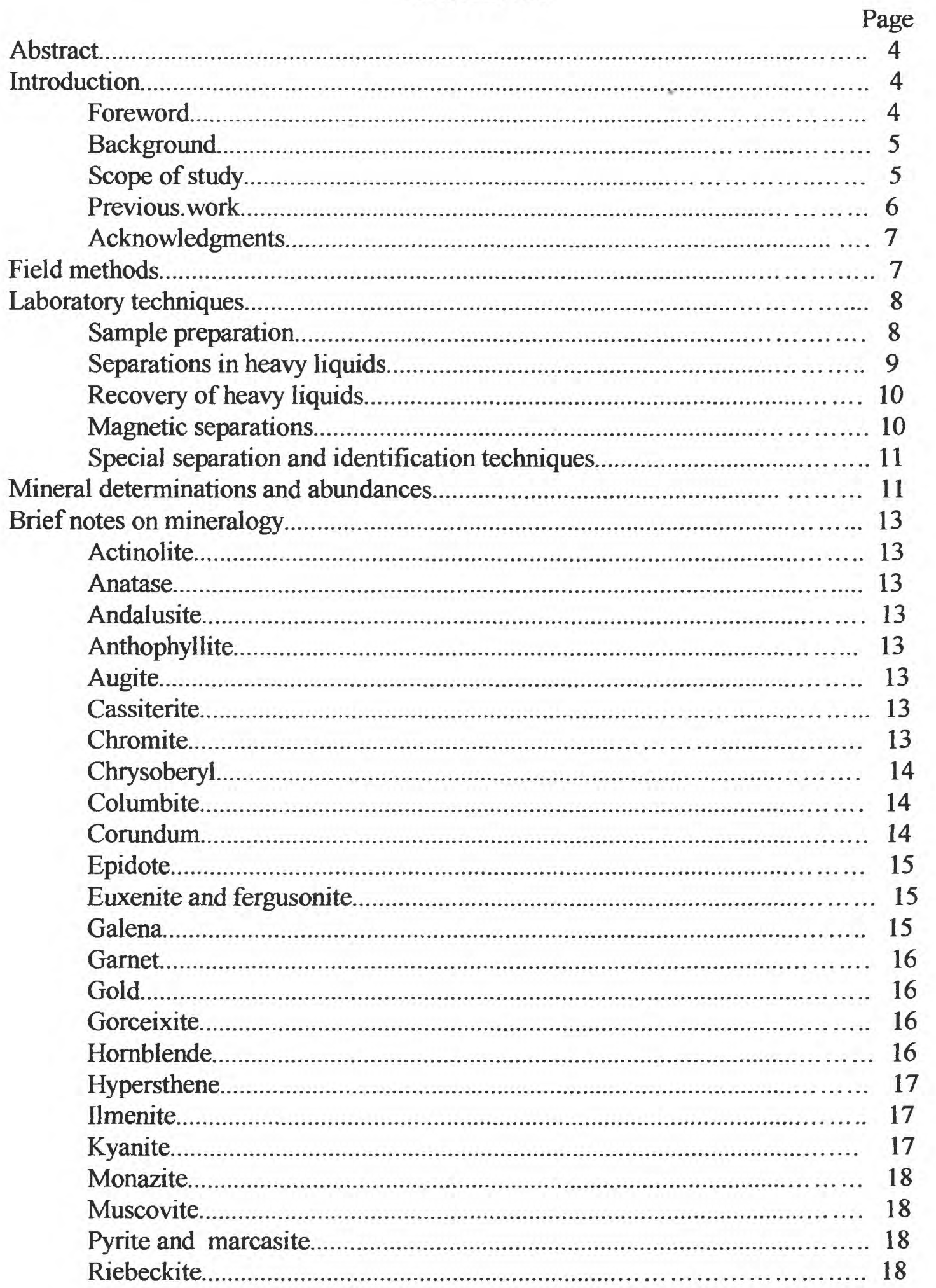


CONTENTS - continued

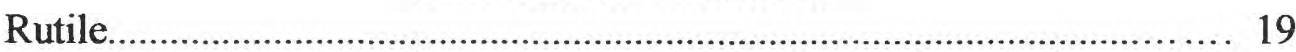

Siderite............................................................................... 19

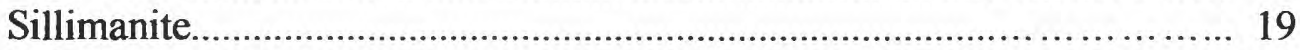

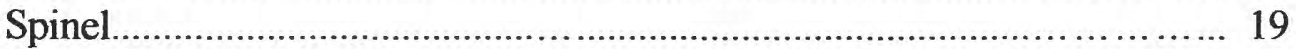

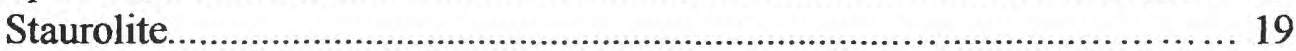

Tourmaline ......................................................................... 20

Xenotime........................................................................ 20

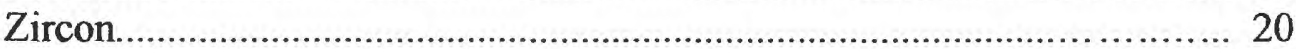

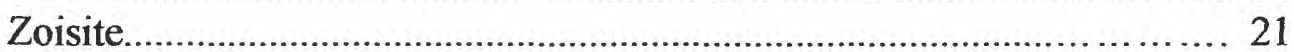

Geology of source terranes................................................................. 21

Sources of potentially commercial minerals................................................. 22

Mineral provinces............................................................ 24

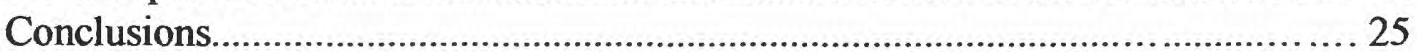

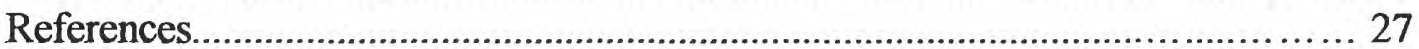

\section{ILLUSTRATIONS}

Figure 1. Diamond Mining Corporation of Liberia prospecting areas,

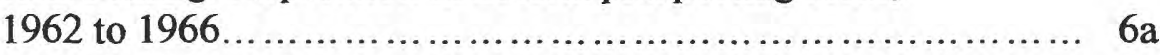

2. Apparatus for heavy-liquid separations...................................... 9a

3. The Frantz magnetic separator................................................. 10a

4. Petrographic and stereomicroscopes for mineral determination......... 11a

5. Mineralogy laboratory equipment...................................... 12a

6. Chromite grains from northwestern Liberia................................ 14a

7. Columbite prisms from central Liberia........................................ 14b

8. Grains of gold in northern Liberia placers.................................. 16a

9. Kyanite and sillimanite grains................................................. 17a

10. Monazite concentrate............................................................ 18b

11. Rutile: a. knee-shaped grains; b. rutile and zircon concentrate....... 19a

12. Siderite crystals.................................................................. 19b

13. Sillimanite concentrate.......................................................... 19c

14. Staurolite concentrate ........................................................... 19d

15. Tourmaline prisms with aligned inclusions................................... 20a

16. Xenotime: a. bipryamids; b. crystals turbid with submicron black

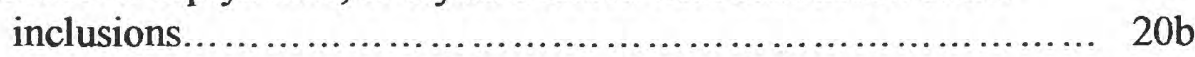

17. Zircon grains.......................................................................... 20

18. Gold occurrences in Liberia....................................................... 24a

19. Map showing areas sampled and approximate mineral provinces..... 24b

20a. Average abundance of heavy minerals in Province 1.................. 25a

20b. Average abundance of heavy minerals in Province $2 \ldots \ldots \ldots \ldots \ldots \ldots . . \ldots 25 \mathrm{~b}$

20c. Average abundance of heavy minerals in Province $3 \ldots \ldots \ldots \ldots \ldots \ldots . . . . . .25 \mathrm{c}$

20d. Average abundance of heavy minerals in Province $4 \ldots \ldots \ldots \ldots \ldots \ldots 2 \mathrm{~d}$

20e. Average abundance of heavy minerals in Province 5.................. 25e

\section{TABLES}

Table 1. Magnetic separation of heavy minerals...................................... $10 \mathrm{~b}$

2. Abundance of heavy minerals in panned concentrates............ $12 \mathrm{~b}$ to $12 \mathrm{~g}$ 
TABLES

Table 1. Magnetic separation of heavy minerals............................................ 9

2. Abundance of heavy minerals in panned concentrates............. 11a to $11 \mathrm{f}$

\title{
METHODS AND PRELIMINARY RESULTS OF HEAVY-MINERAL STUDIES IN LIBERIA
}

\author{
By \\ Sam Rosenblum and G.W. Leo*, U.S.Geological Survey \\ and \\ S.P. Srivastava*, Liberian Geological Survey
}

\begin{abstract}
$\underline{\text { Abstract }}$
A systematic study of heavy detrital minerals was begun in Liberia in June 1966 and by July 1972 more than 2,500 stream and beach panned concentrates were examnined. The heavy minerals in the concentrates were separated in the mineralogical laboratory by gravity and magnetic methods, and 47 different minerals were recognized. Diagnostic and distinguishing features of the typical minerals are described. The area of investigation covers much of western Liberia. Within the area, five mineral provinces were recognized by unusual, distinctive, or predominant mineral assemblages. These assemblages are: (1) sillimanite-kyanite-staurolite-corundum-monazite-gold; (2) almandite-monazite-rutile-xenotime-corundum-gold; (3) monazite; (4) magnetitemonazite-chromite-hypersthene-xenotime-gold; and 5) cassiterite-columbite-tourmalinealmandite-staurolite-andalusite.
\end{abstract}

\section{INTRODUCTION}

Foreword

The work described in this report was done between mid-1966 and mid-1972. The report was written in early 1969 and submitted in mid-1969 for reviews and approval to publish as a U.S. Geological Survey Open-File Report. Somehow, after several reviews, changes, and approvals, the report was unintentionally mislaid in late 1972 and recently found by the senior author among stored documents. Considering the amount of useful work accomplished and the time involved by reviewers and others, the senior author resubmitted the report for publication, using the old cliche "better late than never". We are sure this publication is worth the effort.

* Deceased 
Background

The heavy-mineral studies described below were part of the Geological Exploration and Resources Appraisal (GERA) project, a cooperative effort of the Government of Liberia and the US Agency for International Development, carried out jointly by the Liberian Geological Survey (LGS) and the U.S. Geological Survey (USGS). One of the principal objectives of the GERA project was to determine and evaluate the mineral resources of Liberia. The heavy-minerals investigation was undertaken to serve as a guide to mineral exploration as well as to supply mineralogical clues to the geology of Liberia. Sand samples were collected from streams and beaches in Liberia by geologists of the U.S. Geological Survey and the Liberian Geological Survey and submitted to the LGS Mineralogy and Petrography Laboratory for evaluation.

The purpose of this paper is to describe the laboratory techniques and to present the results and observations of a systematic study of the detrital minerals of Liberia which started in June 1966. This investigation was undertaken by S.P. Srivastava in cooperation with G.W. Leo, USGS mineralogist, who left Liberia in September 1967. Rosenblum joined the project in August 1967, and took over the duties of Leo. As of July 1972 , more than 2,500 samples were examined by Srivastava and 47 different heavymineral species were identified.

Although the study can by no means be considered complete, the results have shed some light on the general nature and distribution of heavy minerals in the western part of Liberia. The results indicate directions for future studies, which may point the way to economic mineral deposits. In fact, data from this investigation was used by an American consulting mining engineer to prospect for and locate gold at 35 localities in western Liberia (P.M. Hopkins, 1973, personal communication). By late 1973, with the sudden rise in gold prices worldwide the Government of Liberia was urging an intensive gold prospecting program utilizing data generated in this investigation.

\section{Scope of study}

The study consists of the mineralogical examination of sand samples panned from streams mainly in Lofa, Grand Cape Mount, and Grand Bassa Counties and from beaches along the Liberian coast. Mineral identifications are based mainly on physical and optical properties, aided by bead, flame, and spot tests as outlined by Smith (1953) and Feigl (1958). In addition, some spectroscopic determinations of metallic elements were made on a visual arc spectroscope. In a few cases, almost pure mineral samples were sent to the U.S. Geological Survey analytical laboratories in Washington, D.C., to obtain chemical, spectrographic, and X-ray data. 
Visual estimates of the abundances of the various minerals were posted on mosaic-block base maps of the collection areas to enable rapid visual comparisons and correlations of the mineral assemblages. Each map covers an area $12 \mathrm{~km}$ north to south and $18 \mathrm{~km}$ east to west at a scale of $1: 40,000$. The mosaic blocks are designated $A$ to $Z$ from the western to the eastern boundary of Liberia, and 1 to 40 from the northern to the southern boundaries (fig. 1). As an example, Monrovia, the capital, lies in Mosaic Blocks E-22 and F-22. These visual aids enabled a semiquantitative synthesis of the data, and the concept of mineral provinces was developed. Bar graphs summarize these data, and are presented to show the mineral assemblages in 5 mineral provinces proposed in this paper.

\section{Previous Work}

Prior investigations of heavy minerals in alluvial deposits in Liberia have resulted in published reports by Offerberg and Tremaine (1961), Leuria (1966), Leuria and Stracke (1966), Stott-Copper (1967), and Thayer, Lill, and Coonrad (1974). Unpublished reports in the GERA files include those by Leuria of the Diamond Mining Corporation of Liberia (DMCL) (1962-1966), Holland Syndicate (1935), Arthur Sherman (1941, 1942), T.P. Thayer (1950), J.G. Richards (1954), and Columbia-Southern Chemical Corporation (1957).

Offerberg and Tremaine indicated that during 1958-60, heavy minerals were panned from alluvial gravels throughout the 50-mile-wide exploration concession area of the Liberian American Swedish Minerals Company (LAMCO), from Buchanan to the Nimba Mine area, covering parts of Montserrado, Bong, Grand Bassa, and Nimba Counties. The samples were analyzed spectrochemically in Stockholm, Sweden, at the Institute of Metallography; some microscopic examinations of the samples were apparently done there also. The spectrographic results were reported in a 1 - 4 system of increasing abundance for $\mathrm{Nb}, \mathrm{Ta}, \mathrm{Cr}, \mathrm{W}, \mathrm{Sn}$, and $\mathrm{Zr}$, and sample suites were shown on three map sheets at 1:125,000 scale. The mineralogy of a few areas was discussed briefly, and included iron minerals, bauxite, possible columbite-tantalite, kyanite, kaolin, ilmenite, rutile, cassiterite, possible chromite or chromium-bearing minerals, gold, zircon, corundum, and diamond.

Leuria (1966) and Leuria and Stracke (1966) briefly discussed kimberlite-related minerals (diamond, ilmenite, garnet, and chrome diopside); and Stott-Cooper (1967) mentioned diamond recovery operations in the Lofa River area. Thayer, Lill, and Coonrad (1974) reported a number of detrital heavy minerals from many samples in western Liberia, but indicated that monazite and tantalite-columbite appear to be the only minerals possibly recoverable in economic quantities during gold or diamond mining. 


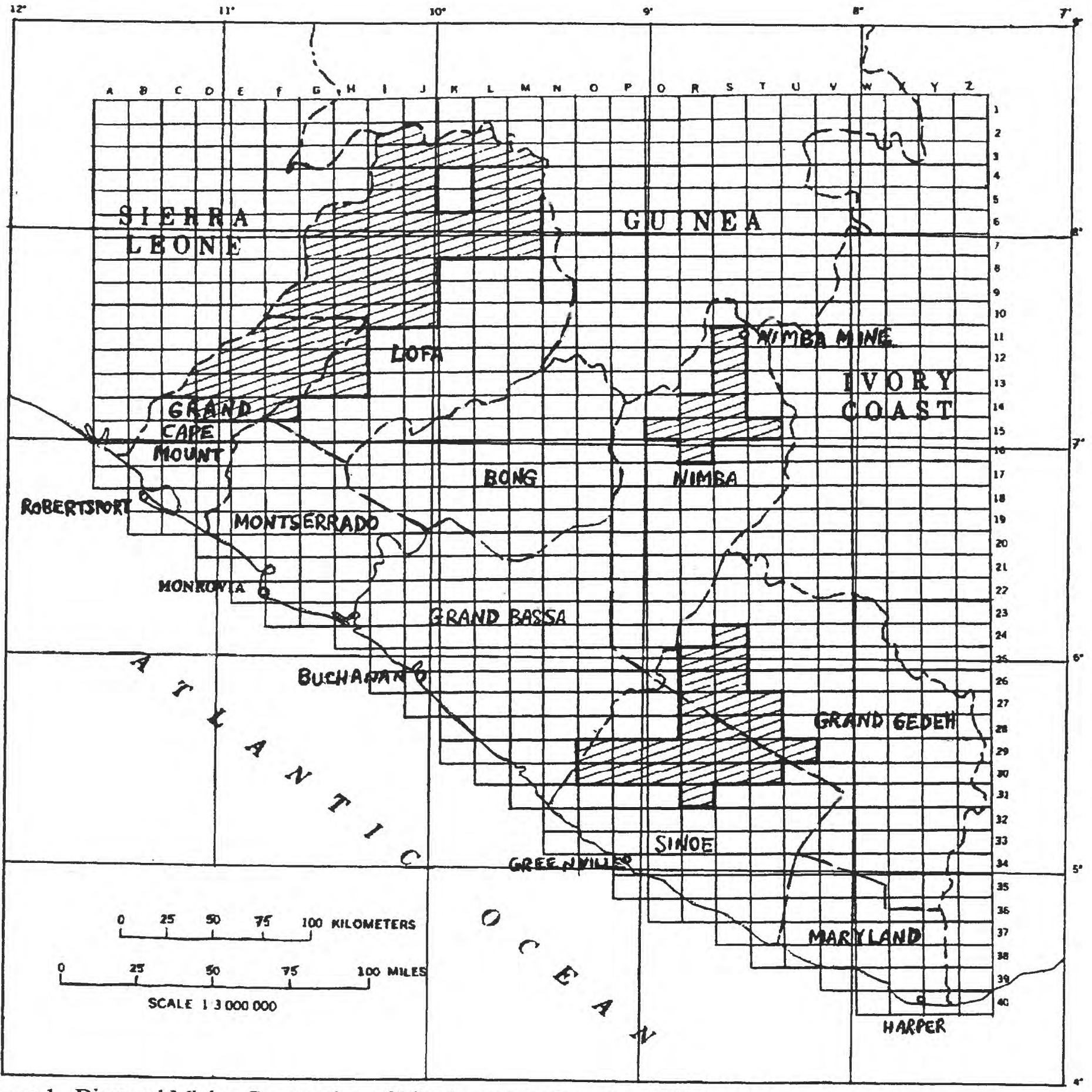

Figure 1. Diamond Mining Corporation of Liberia prospecting area, 1962 to 1966.

Area of operation, shown by mosaic blocks. Mosaic blocks (Table 2) are designated by letters at the top and numbers at the side of the map. 
The DMCL efforts, under the direction of geologist Basil Leuria, concentrated on locating kimberlite pipes in Lofa, Grand Cape Mount, Nimba, Grand Gedeh, and Sinoe Counties via heavy minerals in the streams (see fig. 1). Quarterly, semi-annual, and annual unpublished reports were transmitted to the Government of Liberia, first under the name St. Andrews Securities, Ltd. in 1962-64, then under the Diamond Mining Corporation of Liberia from 1964-66. In addition to diamond and kimberlitic minerals, many tables showed heavy minerals on a frequency scale of 1 to 4 , but the numbers were not equated to percentages. Mineralogical techniques employed and the criteria for recognition of kimberlitic minerals were not indicated.

The Holland Syndicate (unpublished report, 1935) briefly discussed detrital minerals such as gold and diamonds in western Liberia. Sherman (unpublished report, 1941) reported chromite in the Timbo River Cess District [sic]; cassiterite, corundum, and gold in the Tchien district; and placer gold was discussed from many districts in eastern Liberia. Sherman (unpublished report, 1942) discussed placer gold in a number of districts in western Liberia. Thayer (unpublished report, 1950) indicated detrital monazite, tantalite-columbite, ilmenite, zircon, chromite, garnet, and conundum in 25 stream samples from western Liberia. Richards (unpublished report, 1954) discussed placer gold, beryl, rutile, ilmenorutile, columbite-tantalite, garnet, tourmaline, and an unidentified black iron-bearing mineral near Zagbata, in the Kokoya district of central Liberia (Mosaic Block O-18). The Columbia-Southern Chemical Corporation operation was directed toward the discovery of titanium-mineral deposits in Liberian beaches from Robertsport to the St. John River. The results appeared in 1957 in an unpublished company report by H.W. Hockin and consisted of four text pages, a number of charts, maps showing drill-hole locations, tables, and mineralogical and X-ray spectrographic data. Minerals discussed included ilmenite, hematite-ilmenite, rutile, monazite, zircon, and magnetite.

\section{Acknowledgments}

We are grateful to W.L. Coonrad for a number of suggestions that helped improve the paper. We express our gratitude to the analysts and staff of the USGS Analytical Laboratories for the chemical and spectrographic data herein presented. Also, we are grateful to the staff of the LGS Mineralogical Laboratory for the many tasks required to yield the materials examined. We especially want to thank Samuel Smith, David Cooper, Fred Okyne, and Jallah Kamara.

\section{FIELD METHODS}

Although the purpose of this paper is to describe laboratory techniques and findings, a brief account is given of the field sampling techniques used to obtain representative samples. Beach sand samples were panned from well-sorted layers of dark-colored sand, usually $0.1-1.0 \mathrm{~mm}$ grain size. Except for hydrous iron oxide coatings on sand grains, there were no clay-size particles and generally no silt-size grains. 
Stream samples are generally taken from the slip-off slope of a curve in the stream, or in the center of a wide shallow stretch of stream where heavy minerals are expected to be naturally concentrated. Gravel is spaded into a square sieve with a 7-10 $\mathrm{cm}$ high wooden frame and a $2 \mathrm{~mm}$-opening screen. A large gold pan is held under this jig and the two are shaken together in the stream just below the water surface to wetsieve the fine fraction; the coarse fraction is discarded after a cursory inspection for heavy minerals. During wet-sieving and panning, a large quantity of clay and silt particles is washed out of the gravel, and the final concentrate is usually free of clay. When the pan is full of sand, the jig is removed and the sand is panned until several grams of dark concentrate is obtained. Formerly the geologist panned the sand down to 2-15 grams of black sand. In the last half of the project, with a Wilfley table in the LGS Laboratory, he was encouraged to pan out about half or two-thirds of the light portion of the sample and bring the remainder into the laboratory for less time-consuming and more efficient separation on the table. In places, two to four pans of sand were required to obtain at least 1 gram of heavy minerals in the concentrate, the minimum acceptable for making visual estimates of frequency percentages.

\section{LABORATORY TECHNIQUES}

\section{Sample preparation}

The separation and recovery of heavy minerals from heterogenous materials is an essential preliminary step to detailed mineralogical studies. A number of methods of mineral separation are available, some of which were originally developed for large-scale commercial operations; adaptations for laboratory methods suitable to the needs of the GERA program are described here in some detail.

Because the majority of the samples studied in the laboratory were panned concentrates of beach and stream sands, no crushing was required. The samples were washed with acetone and quickly dried under heat lamps prior to sieving into different size fractions. Large samples were formerly reduced by simply coning and quartering to obtain a representative split of the bulk sample; a Jones-type sample splitter was used later in the operation for this purpose.

The dried samples were then passed through a 60 -mesh screen $(0.25 \mathrm{~mm}$ opening) and graded into coarser ( +60 mesh) and finer ( -60 mesh) sizes. When fine particles were excessive, a 120 -mesh screen $(0.125 \mathrm{~mm}$ opening $)$ was used to remove the finer materials in order to have a more uniform product to increase the efficiency of subsequent separatory methods. In the early stages of the investigation, the sieving operations were carried out manually; later an automatic electric sieve shaker with stainless steel sieves was used to achieve uniform sizing. After every use, all the sieves were carefully cleaned with a soft brass-wire or nylon brush. 
Separations in heavy liquids

Separation of minerals in heavy liquids is based on differences in density between associated minerals. A suitable heavy liquid is chosen with a density such that the desired mineral or minerals sink in the liquid while the unwanted minerals float. A list of heavy liquids and solutions has been given by Milner (1962, v. 1, p. 119-120). For the most part, bromoform (density 2.85 at $20^{\circ} \mathrm{C}$ ) and methylene iodide (density 3.20 at $20^{\circ} \mathrm{C}$ ) were used during the present investigation. Bromoform, because of its lower viscosity and lower cost, was found to be the more favorable liquid for rapid settling and fast filtration, especially when separating a large number of samples.

The apparatus commonly used in mineralogical laboratories for heavy-liquid separations is shown in figure 2 . The minus- 60 mesh fraction, which usually forms 70 to 90 percent of the sample, was poured into the separatory funnel and stirred several times to ensure complete separation. Whatman No. 541 fast-filtering paper was used and filtration was accelerated by an aspirator connected to the filtering flask by rubber tubing. Both the heavy and light fractions were washed free of the heavy liquid with acetone and subsequently dried under heat lamps. When dried, the heavy residue was ready for further separation in a magnetic separator. Bottles to hold the bromoform and methylene iodide washings for subsequent recovery of the heavy liquids were plainly labeled to avoid accidental contamination.

Separation of heavy minerals from coarser fractions (plus-60 mesh) was seldom made; however, when desired, it was carried out in a heavy liquid by the open-dish method. The coarse fraction of the sample was carefully poured into a suitable beaker that was half filled with heavy liquid, and stirred until the separation was considered complete. The container was then tilted to decant the floating minerals onto a filter paper. This procedure was repeated if the separation was not complete. Finally, the heavy liquid was recovered, and the heavy fraction was then washed with acetone and dried.

Clerici solution was used in special cases where it was desired to separate a particular mineral or suite of minerals with density (D) greater than 5.0 from an initially separated bromoform concentrate. Fairly pure fractions of monazite were conveniently separated from a mixture of zircon $(D=4.7)$, rutile $(D=4.2)$, and monazite $(D=5.1)$ in this heavy liquid. Clerici solution is a saturated solution of equal weights of thallous formate and thallous malonate in distilled water and it has a density of 4.28 at room temperature. A saturated solution at $50^{\circ} \mathrm{C}$ has a density of 4.7 , and at $90^{\circ} \mathrm{C}$ the density of the saturated solution is 5.0 (Muller, 1967, p. 9). Extreme care is needed in handling because the solution is poisonous and may be absorbed through the skin. 


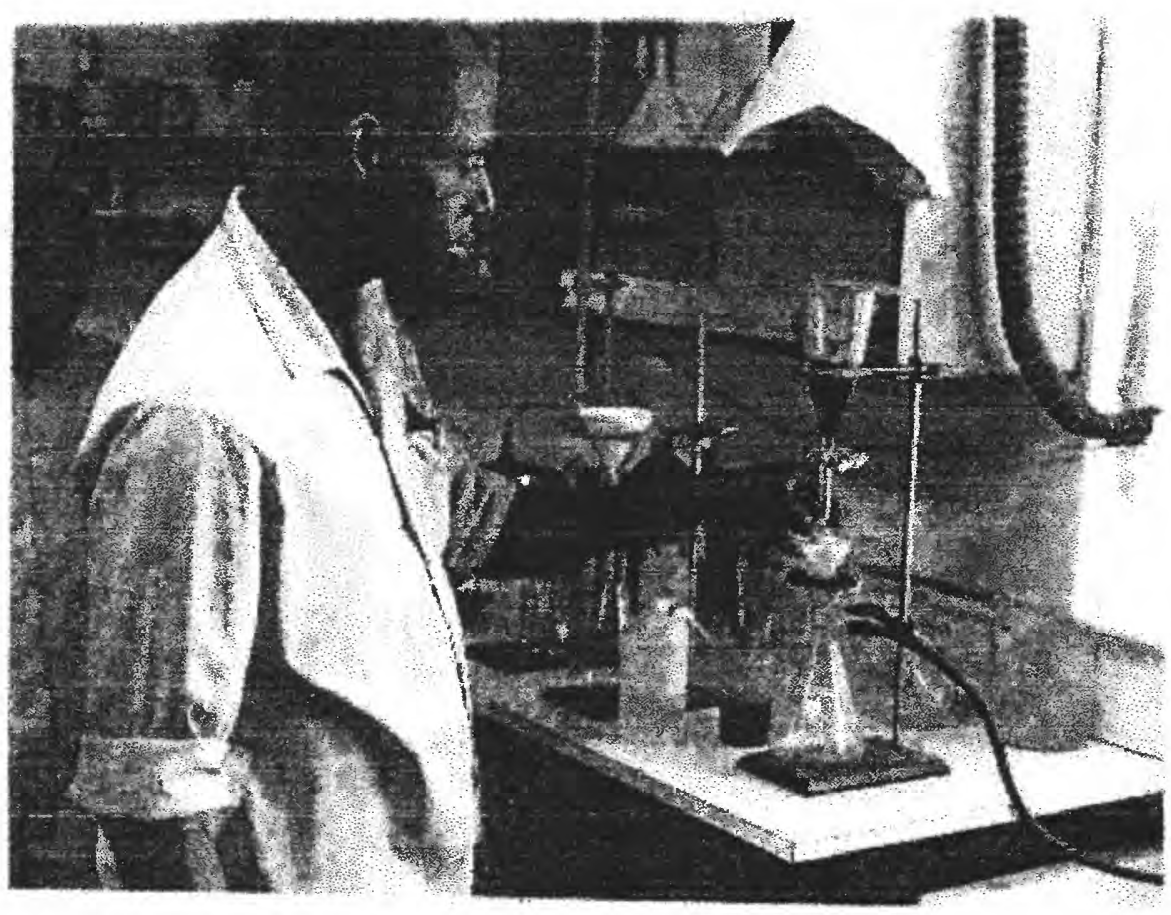

Figure 2. Apparatus for heavy-liquid separations 
Recovery of heavy liquids

The recovery of heavy liquids was an important routine laboratory task as these liquids were expensive and difficult-to-obtain items. Normally, the recovery of bromoform or methylene iodide from acetone washings is achieved by fractional distillation of the acetone at about $57^{\circ} \mathrm{C}$. After recovery of about 90 percent of the acetone, the heavy liquid was washed free of acetone by vigorously shaking the residue in a large bottle, several times, in large amounts of water. The bottle was then left standing overnight to permit complete settling of the heavy liquid. The major portion of the water is carefully decanted and bromoform or methylene iodide is separated from the water layer by means of a separatory funnel, passed through filter paper to remove traces of water, and finally checked for density to verify the purity of the liquid.

With repeated use, heavy liquids usually become darker in color making their continued use rather difficult. Decolorization of these liquids may be achieved by shaking with activated charcoal or Fuller's earth and the liquid is ready for reuse after filtration. In stubborn cases the heavy liquid is distilled and the small amount of remaining color in the distillate may be removed by shaking with 10 percent (aqueous)sodium hydroxide in a separatory funnel.

\section{Magnetic separations}

The highly magnetic minerals (ferromagnetics), such as magnetite and some picroilmenite, were readily separated by use of a horseshoe magnet, the poles of which were covered by thin powder paper (glassine) to facilitate subsequent release of the ferromagnetic minerals. Alternatively, the magnet keeper was used on end in place of the paper. In practice, the sample was spread on white paper as a uniform layer one grain thick (as nearly as possible) and the magnet was passed closely over but did not touch the sample. This was repeated several times to ensure complete extraction. The ferromagnetics were dropped into a porcelain dish by removing the magnet from the powder paper or the keeper. To avoid trapped nonmagnetic minerals, repetition of the above procedure three times usually yielded a clean magnetic concentrate, and the nonmagnetic minerals were returned to the nonmagnetic fraction.

In the Frantz Separator (fig. 3) a less magnetic group of minerals (paramagnetics) was extracted in three fractions plus a nonmagnetic residue (diamagnetics), to permit rapid identification and quantification of the heavy minerals. Hess (1956), Rosenblum (1958), and Flinter (1959) have described and referenced data on operation of this magnetic separator. All samples were separated at $0.45,0.7$, and 1.4 amperes at $20^{\circ}$ side slope and $23^{\circ}$ forward slope. Table 1 gives the distribution of some of the common minerals grouped according to their magnetic susceptibilities, as observed in the LGS laboratory. Partly altered ilmenite, magnetite, almandite, hornblende, and augite may appear in less magnetic fractions. Conversely, altered zircon and monazite and minerals with magnetite inclusions may be found in more magnetic fractions. After the first pass at 0.45 amperes, a small amount of ferromagnetics may be recovered by turning off the current to the coil and allowing the ferromagntic minerals caught in the pole pieces to be vibrated down the chute and collected on a piece of paper. These represent magnetic minerals trapped in the less magnetic fraction during initial hand-magnet removal of the ferromagnetics. 


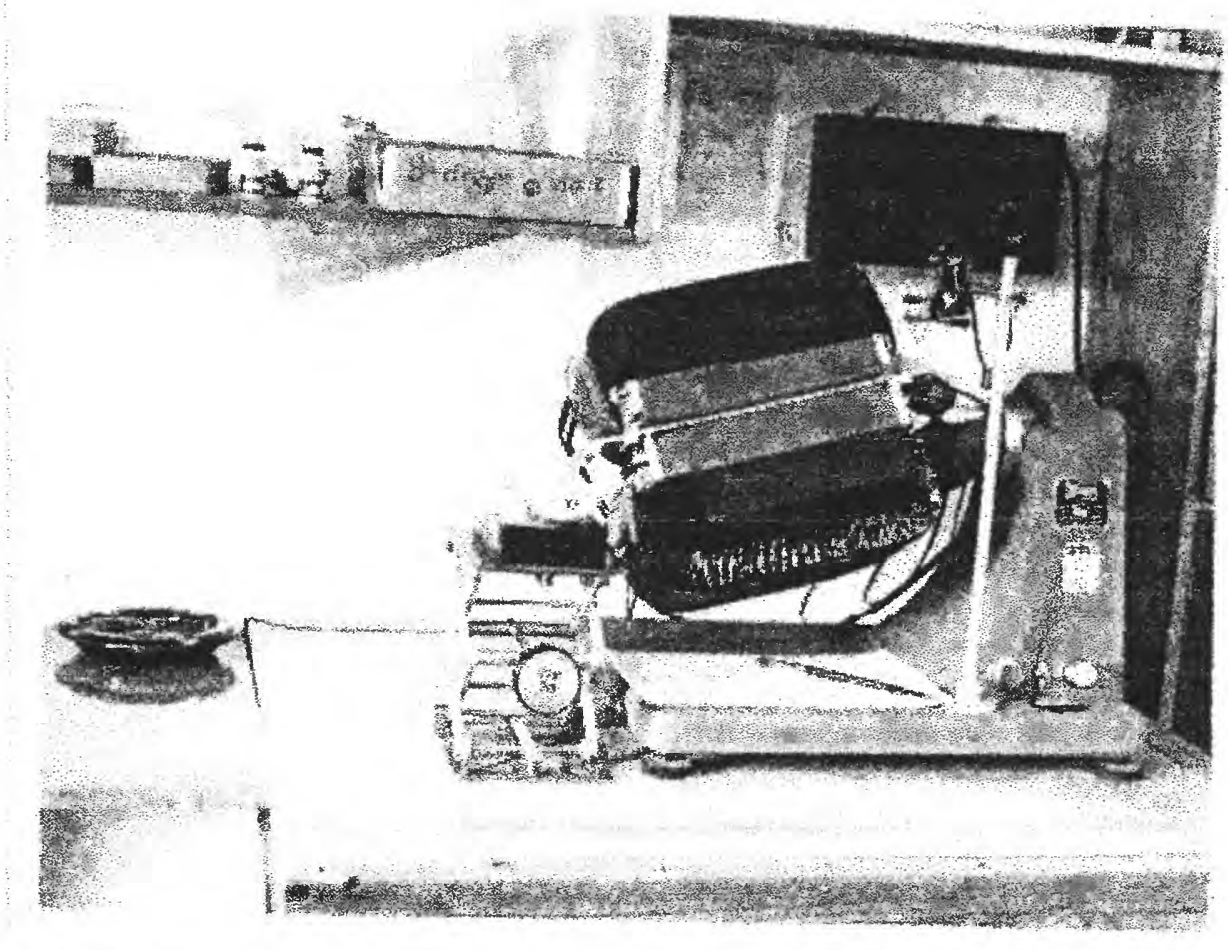

Figure 3. The Frantz magnetic separator 
Table 1.-- Magnetic separation of heavy minerals

Extracted by $\quad$ Extracted by Frantz magnetic separator at $20^{\circ}$ side slope and $23^{\circ}$ hand magnet forward slope (values in amps.)

\begin{tabular}{|c|c|c|c|c|}
\hline \multirow[t]{2}{*}{ Ferromagnetic } & \multicolumn{3}{|c|}{ Paramagnetics } & \multirow{2}{*}{$\begin{array}{c}\text { Diamagnetics } \\
\text { over } 1.40\end{array}$} \\
\hline & $\underline{0-0.45}$ & $\underline{0.46-0.70}$ & $\underline{0.71-1.40}$ & \\
\hline $\begin{array}{l}\text { magnetite } \\
\text { picroilmenite }\end{array}$ & $\begin{array}{l}\text { picroilmenite } \\
\text { ilmenite } \\
\text { almandite } \\
\text { chromite } \\
\text { hypersthene } \\
\text { hematite } \\
\text { limonite } \\
\text { siderite } \\
\text { malacon }\end{array}$ & $\begin{array}{l}\text { hypersthene } \\
\text { chromite } \\
\text { hornblende } \\
\text { augite } \\
\text { epidote } \\
\text { anthophyllite } \\
\text { staurolite } \\
\text { spinel } \\
\text { xenotime } \\
\text { actinolite } \\
\text { biotite } \\
\text { hematite } \\
\text { limonite } \\
\text { tourmaline } \\
\text { pyrope } \\
\text { malacon } \\
\text { columbite } \\
\text { monazite } \\
\text { picroilmenite }\end{array}$ & $\begin{array}{l}\text { monazite } \\
\text { actinolite } \\
\text { tremolite } \\
\text { rutile } \\
\text { zircon } \\
\text { tourmaline } \\
\text { spinel } \\
\text { anatase } \\
\text { corundum } \\
\text { clinozoisite } \\
\text { sphene } \\
\text { sillimanite } \\
\text { kyanite } \\
\text { muscovite } \\
\text { zoisite } \\
\text { pyrope }\end{array}$ & $\begin{array}{l}\text { zircon } \\
\text { rutile } \\
\text { sillimanite } \\
\text { kyanite } \\
\text { corundum } \\
\text { pyrite } \\
\text { gold } \\
\text { cassiterite } \\
\text { anatase } \\
\text { apatite } \\
\text { muscovite } \\
\text { andalusite } \\
\text { galena } \\
\text { leucoxene } \\
\text { marcasite }\end{array}$ \\
\hline
\end{tabular}




\section{Special separation and identification techniques}

Rapid concentrations of cassiterite were made in a $50 \mathrm{ml}$ burette filled with methylene iodide $(\mathrm{D}=3.20)$, utilizing the principle of differential settling due to differences in densities of minerals. After close sizing, a small amount of the sample is poured into the top of the burette. Cassiterite $(D=6.8$ to 7.1$)$, usually the heaviest mineral in the assemblage, settles to the bottom first and is tapped off onto a filter paper. When the rest of the sample settles, it is recovered on another filter paper, and the burette is refilled with methylene iodide, and the process repeated until the whole sample is treated. The cassiterite concentrate is washed with acetone, dried, and small amounts of impurities are removed by hand picking.

Rapid identification of cassiterite in the nonmagnetic fraction is made by treating the sample with hydrochloric acid (1:1) on a zinc plate. Following subsidence of the effervescence, all cassiterite grains are identified under the stereomicroscope by a bright coating of metallic tin, and visually estimated.

After heating to redness before a blowpipe, siderite grains become ferromagnetic and cooled grains jump to a magnet. No other carbonate mineral shows this property; hence, this is a positive test for siderite.

\section{MINERAL DETERMINATIONS AND ABUNDANCES}

Forty-seven different mineral species were identified during this study, mainly by their physical and optical properties. With some experience, the common minerals are identified on the basis of form, color, pleochroism, relative relief in immersion oils, alteration products, typical inclusions, amount of birefringence, extinction angle, sign of elongation, optic sign, and size of optic axial angle. Less common minerals may require determination of the major elements in a visual-arc spectroscope, or an X-ray powder diffraction pattern to help determine the species.

Physical properties were ascertained under a stereomicroscope, and optical determinations were made utilizing a petrographic microscope (fig. 4). Standard references such as Ford (1932), Winchell and Winchell (1951), Troger (1952), Deer and others (1962), and Palache and others (1944) were consulted for precise identification of mineral species. Quantitative measurements of optical properties, such as the optic axial angle (2V) and refractive indicies were made on some of the mineral grains with the aid of the spindle stage (Wilcox, 1959 1960; Roy, 1965). For grains between 1 and $100 \mathrm{mg}$, which are not likely to contain impurities, determination of the specific gravity was carried out on a Berman balance (fig. 5). 


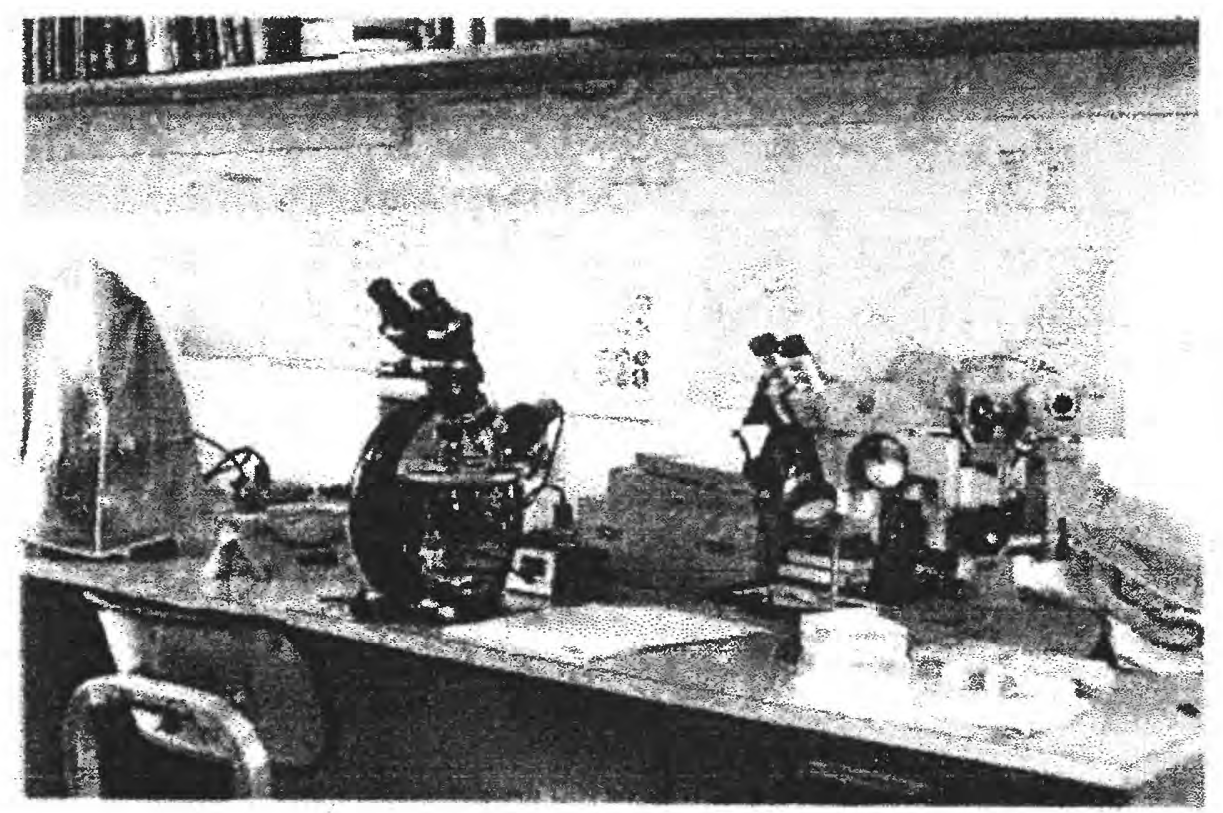

Figure 4. Petrographic and stereomicroscopes for mineral determination 
Standard refractive index liquids from 1.41 to 2.11 , calibrated in 0.01 intervals, were used for the determination of the principal refractive indicies of the transparent and translucent minerals. Recalibration of the most volatile index liquids, those between 1.71 and 2.11 at room temperatures $\left(23^{\circ}\right.$ to $26^{\circ} \mathrm{C}$.), were made from time to time using the sodium-vapor lamp and the Leitz-Jelly refractometer shown in fig. 5. For liquids with refractive indices less than 1.71, an Abbe-type refractometer was available. An ocular spectroscope was used with the petrographic microscope to check absorption spectra to confirm the identity of non-opaque rare-earth minerals, such as monazite and xenotime.

The abundances of the various heavy minerals were first determined by estimating the grain percentages in the magnetic fractions of each sample. Average grain percentage ranges of individual minerals were estimated visually, aided by charts for estimating pecentage of particles in a microscopic field (Compton, 1962, p. 332-333)

To represent the frequencies of the different minerals, the following scheme was adopted:

\begin{tabular}{|c|c|c|}
\hline Visual amount & Grain percent & Abundance value \\
\hline Trace, $\mathrm{T}$ & $0-1$ & 1 \\
\hline Rare, R & $1-5$ & 2 \\
\hline Scattered, S & $5-10$ & 3 \\
\hline Common, $\mathrm{C}$ & $10-20$ & 4 \\
\hline Abundant, A & over 20 & 5 \\
\hline
\end{tabular}

Table 2 shows the abundance values of the 38 most abundant minerals recognized in concentrates mainly from western Liberia. The minerals are listed alphabetically and abundances are shown by mosaic block. The samples were typical of those found in the mosaic blocks and were selected on the basis of two criteria: a minimum weight of 2 grams, and a maximum number of mineral species that represent most samples from the mosaic block.

The minerals are generally displayed as families. However, two species of garnet (almandite and pyrope), three amphiboles (actinolite, anthophyllite, and hornblende), two pyroxenes (augite and hypersthene), two micas (biotite and muscovite), three epidotes (clinozoisite, pistacite, and zoisite), and two types of ilmenite (ilmenite and picroilmenite) are listed separately. The secondary iron oxides, hematite and limonite, are grouped together. Rare minerals identified in some of the samples were not included in the table because of their scarcity, or were discussed with other species because of close similarity: eulite was grouped with hypersthene, malacon with zircon, marcasite with pyrite, piedmontite with epidote, and riebeckite with hornblende. Chrysoberyl, gorceixite, euxenite, and fergusonite occurred in insignificant amounts. 


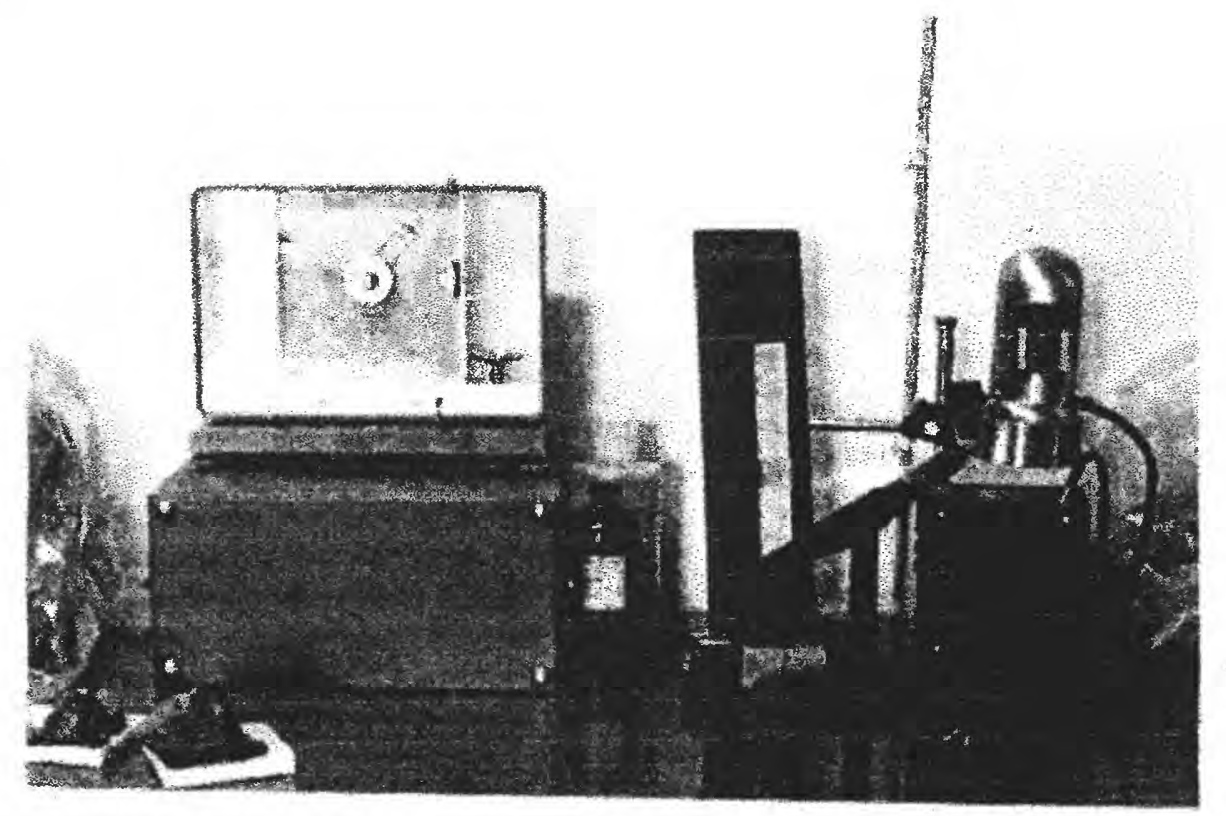

Figure 5. Mineralogy laboratory equipment. Berman balance (left) for specific gravity determinations in the $1-100 \mathrm{mg}$ range. Refractometer and sodium vapor lamp (right) for calibration of refractive index liquids. 


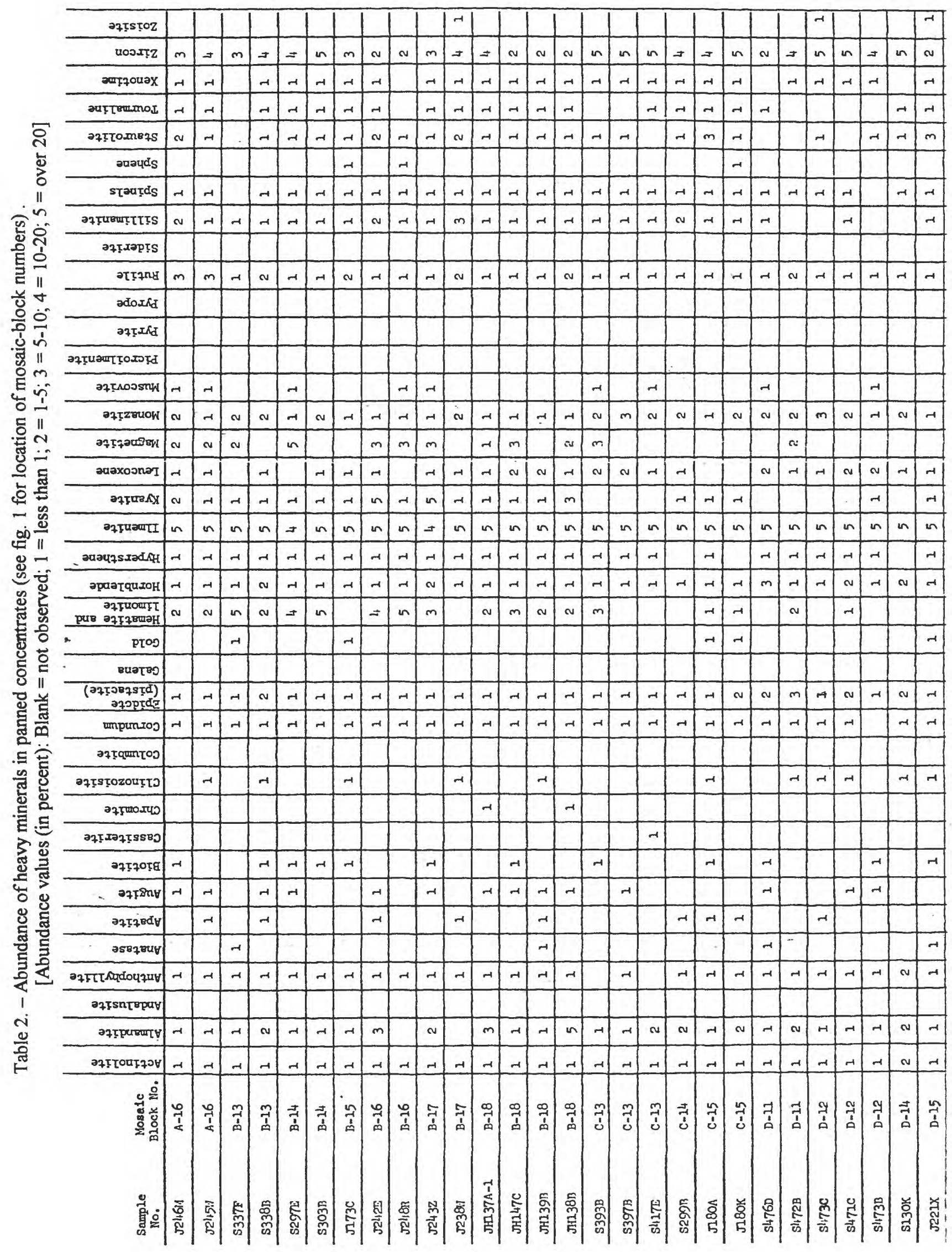




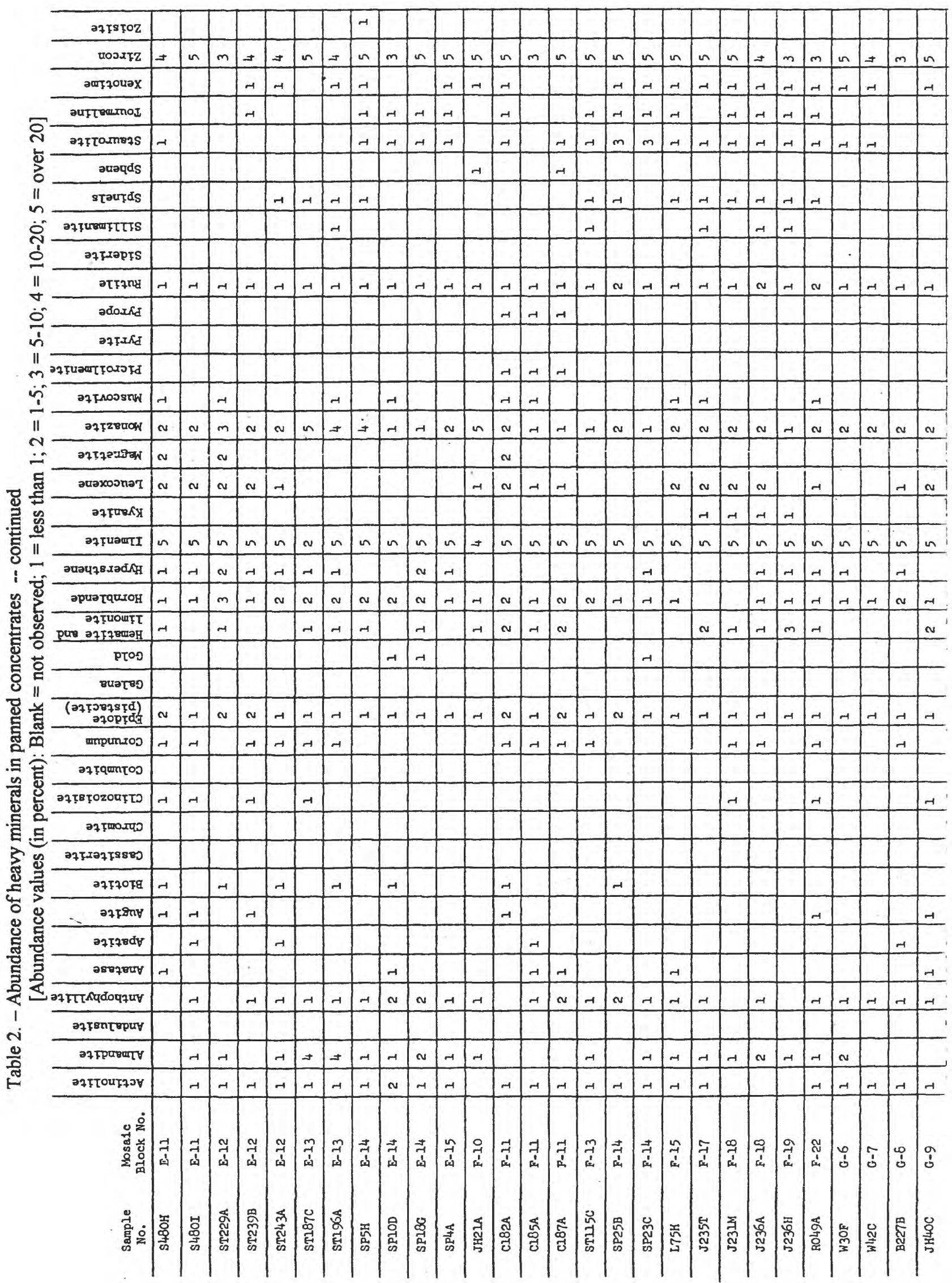




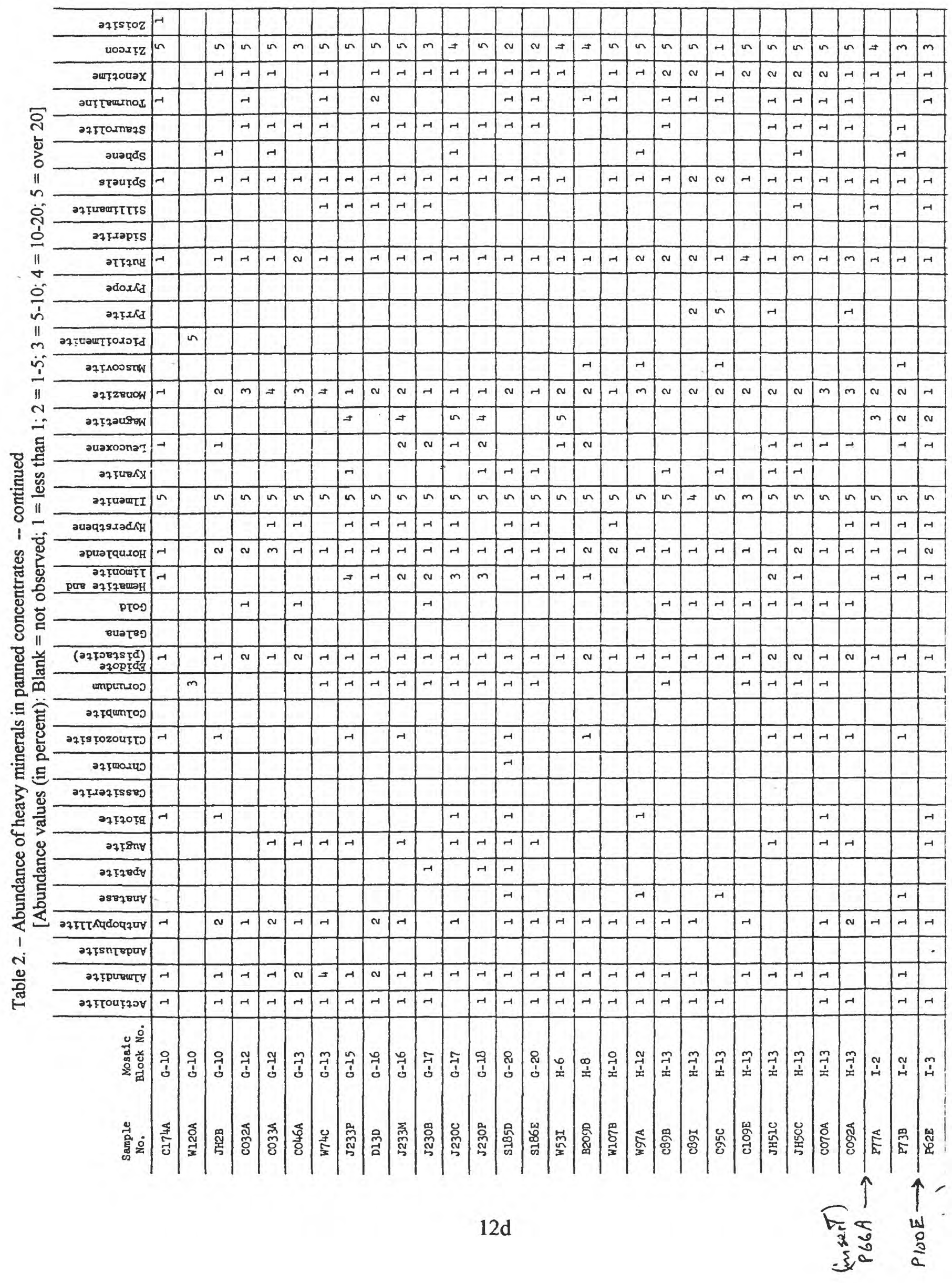




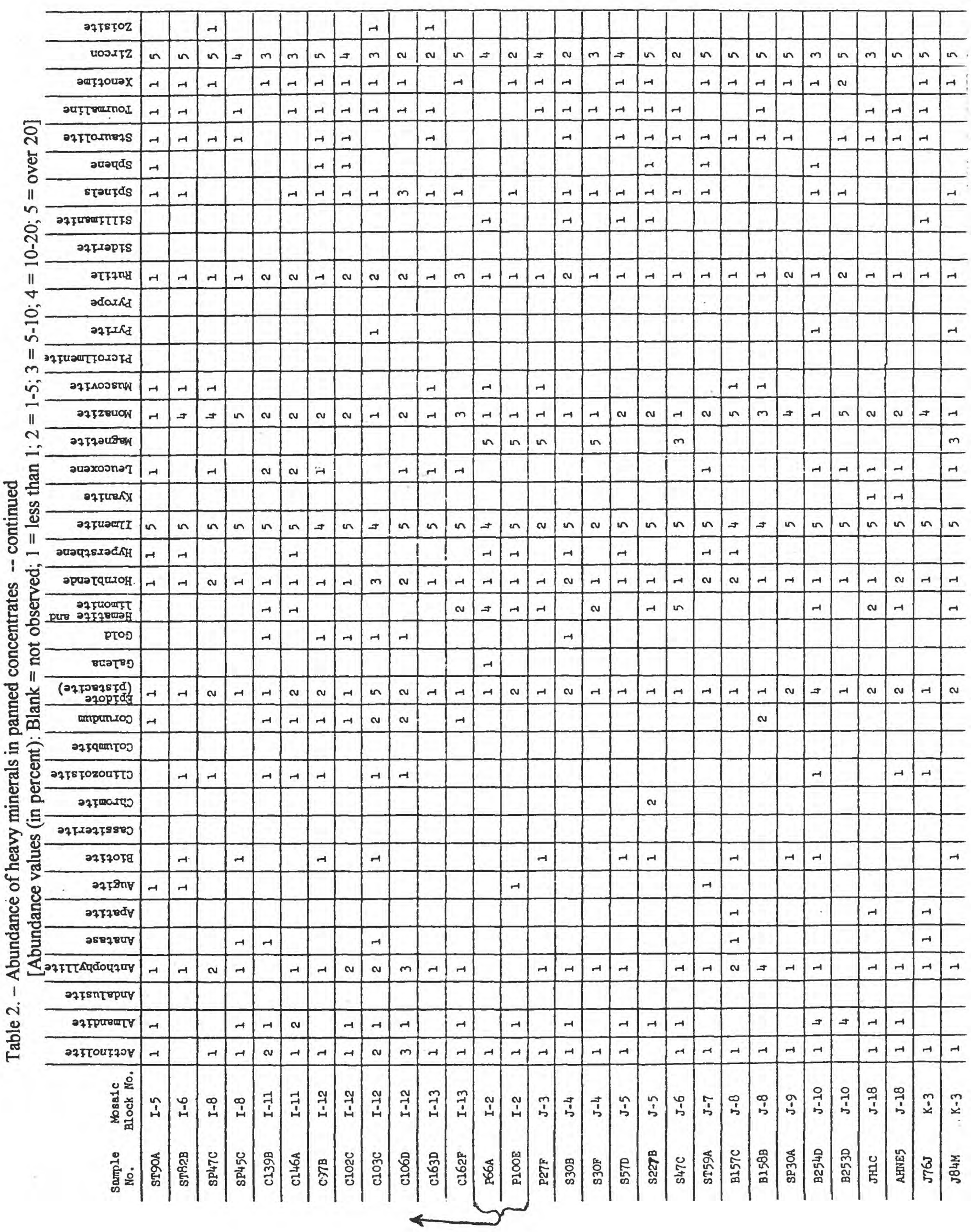




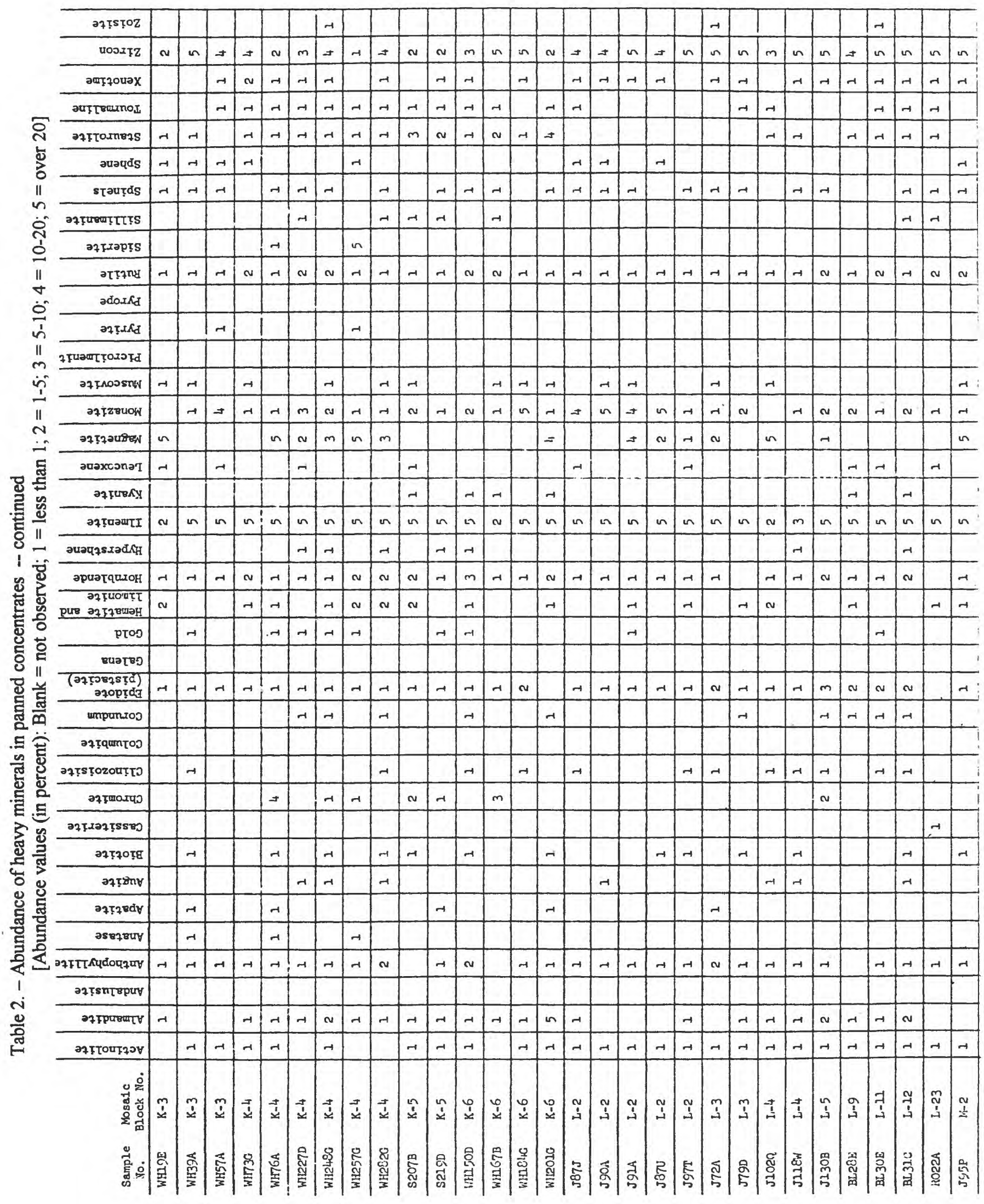




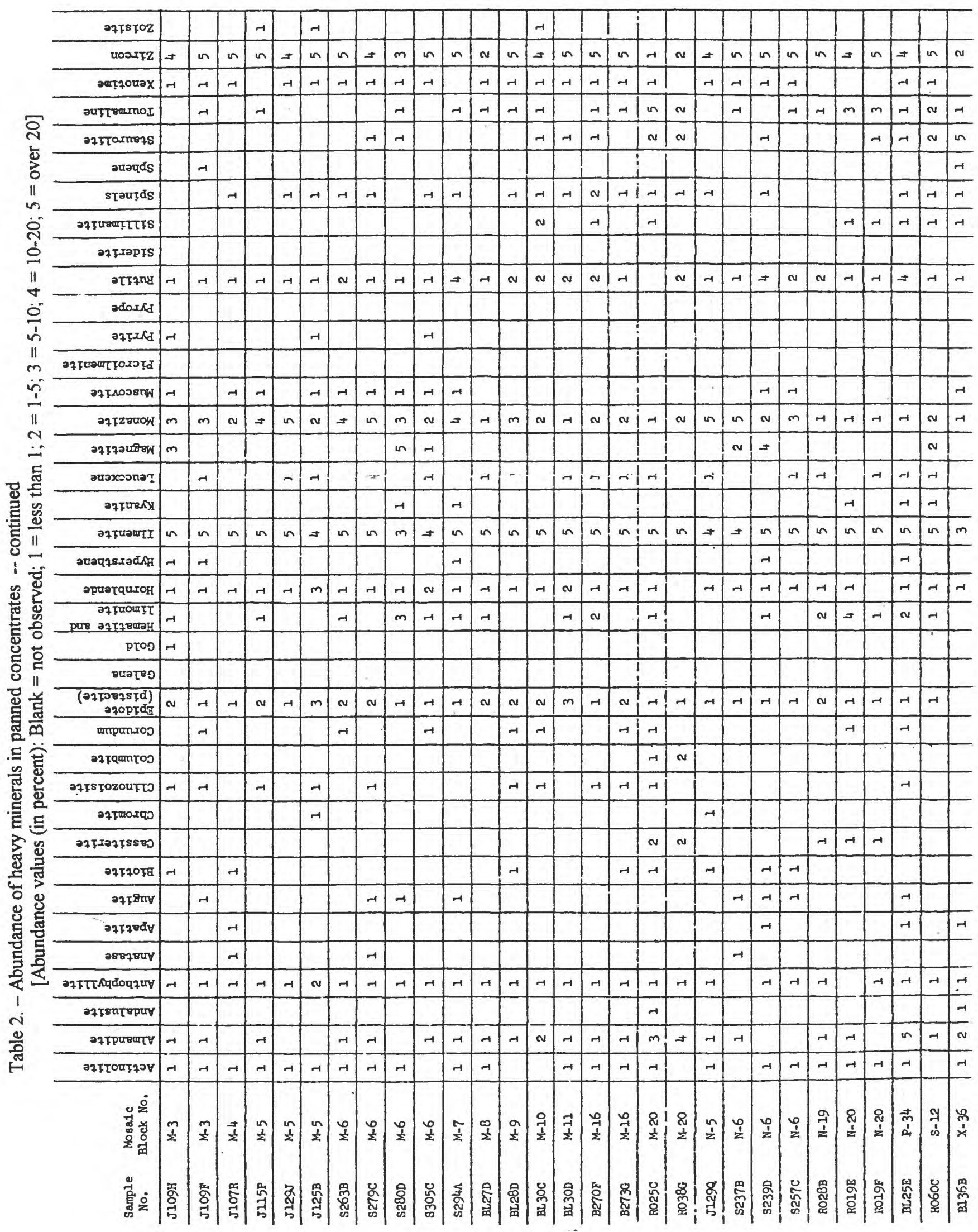




\title{
BRIEF NOTES ON MINERALOGY
}

\author{
Actinolite
}

Actinolite was recognized by its distinctive bladed form; perfect prismatic cleavages; yellowish-green color with weak pleochroism: $\mathrm{X}=$ pale yellow, $\mathrm{Y}=$ pale green, $\mathrm{Z}=$ green, $\mathrm{Z}: \mathrm{c}=15^{\circ}$ to $16^{\circ}, \mathrm{N}_{\mathrm{x}}=1.62, \mathrm{~N}_{\mathrm{z}}=1.65$, and $(-) 2 \mathrm{~V}=80^{\circ}$.

Actinolite grains were found in most of the heavy-mineral samples. Many samples from areas underlain by amphibolites are predominantly of this mineral (for example, Mosaic Block E-13). The colorless variety, tremolite, was not recognized in heavy-mineral concentrates.

\section{Anatase}

Anatase grains are typically yellow-brown with very high relief. The grains usually lie on the (001) cleavage and show well-centered uniaxial negative figures. Inclusions of dark brown to black materials (magnetite, ilmenite, or carbon) are noted along the margins of every grain. Anatase is sparsely distributed among the samples.

\section{Andalusite}

Andalusite occurs as stubby orthohombic prisms and is recognized by its distinctive length-fast character and weak birefringence; $\mathrm{N}_{\mathrm{x}}=1.63, \mathrm{Nz}=1.64$, and () $2 \mathrm{~V}=85^{\circ}$. It characteristically contains many inclusions, and is found in few samples throughout Liberia.

\section{Anthophyllite}

Anthophyllite is typically colorless, rarely pale green, and irregularly iron-stained. It is prismatic, with parallel extinction, a feature which distinguishes it from minerals of the tremolite-actinolite series. Birefrigence is strong, $\mathrm{N}_{z}=1.64$, it is length slow, and $(+) 2 \mathrm{~V}$ is usually very large $\left(80^{\circ}\right.$ to $\left.90^{\circ}\right)$. Anthophyllite was found in numerous stream samples. It is derived from iron-rich metamorphosed rocks such as iron-silicate formation and in iron ore, as at Bomi Hills.

\section{Augite}

Augite grains are identified by their characteristic stubby prisms, greenishbrown color, strong birefringence, $\mathrm{N}_{z}=1.72, \mathrm{Z}: \mathrm{c}=45^{\circ}$ to $50^{\circ}$, and $(+) 2 \mathrm{~V}=50^{\circ}$ to $60^{\circ}$. Most of the grains show good prismatic cleavages. Augite grains are common in many heavy-minerals amples, especially those from near outcrops of diabase dikes.

\section{Cassiterite}

Cassiterite grains were recognized mainly in samples collected from the middle and lower St. John River area in central Liberia. Grains are typically dark brown to black, equant, angular to rounded, and difficult to distinguish from rutile in sands except by the special technique noted under "Special separation and identification techniques". $\mathrm{N}_{\mathrm{e}}=2.10, \mathrm{~N}_{\mathrm{o}}=2.00$, and dichroism in light brown is weak.

\section{Chromite}

Chromite is normally extracted in the Frantz separator between 0.3 and 0.7 amp. Usually it shows well-developed octahedrons to round, equant, dark brown to black 
grains (see fig. 6). Crushed grains are brown to reddish brown on thin edges. The mineral is typically translucent, with very high relief $(\mathrm{N}=2.00$ to 2.10$)$, and is isotropic. Panned samples from the Wologizi area (Mosaic Blocks K-4, K-5, and K-6) showed the greatest percentages of chromite, up to 30 percent of the heavy minerals. Traces of chromite are also found elsewhere (Leo and Holmes, 1968).

Beach sand samples from the Robertsport area (Mosaic Blocks A-16, B-17, C-19 and D-30) have chromite grains comprising up to 1 percent of the heavy minerals. An unusual feature of these samples is the occurrence of chromite (?) in the ferromagnetic fraction. Spectrographic tests of three samples showed 3 to 10 percent chromium, 500 to $700 \mathrm{ppm}$ (parts per million) manganese, 70 to $100 \mathrm{ppm}$ cobalt, 500 to $700 \mathrm{ppm}$ copper, 700 to $1500 \mathrm{ppm}$ nickel, and $1500 \mathrm{ppm}$ vanadium.

\section{Chrysoberyl}

Only two stream samples, both from Mosaic Block E-16, contained yellow vitreous grains of chrysoberyl $\left(\mathrm{BeAl}_{2} \mathrm{O}_{4}\right)$. The grains have conchoidal fracture, $\mathrm{N}_{\mathrm{x}}=$ $1.760, \mathrm{~N}_{\mathrm{z}}=1.765,(+) 2 \mathrm{~V}=80^{\circ}$ to $90^{\circ}$, and dispersion, $\mathrm{r}<\mathrm{v}$ is strong. An $\mathrm{X}$-ray powder pattern confirmed the identity. The source of this material is not known, but presumably it is derived from a pegmatite, perhaps the same one that supplied corundum, spinel, euxenite, and fergusonite found in the same samples.

\section{Columbite}

Distinctive brown-black lath-shaped crystals of columbite were recognized only in cassiterite-bearing samples from Mosaic Block M-20 in central Liberia. The grains are extracted in the 0.4 to $0.7 \mathrm{amp}$. range in the magnetic separator, they are usually about $0.3 \mathrm{~mm}$ wide and up to $3 \mathrm{~mm}$ long, and they are subhedral to broken and slightly rounded (fig. 7). Crushed grains are translucent-brown on thin edges and show weak birefringence in strong light. Refractive indices are about 2.3; and spectroscopic tests confirmed niobium but little or no tantalum was detected. A specific gravity of 5.76 was obtained on $24 \mathrm{mg}$ of hand-picked grains; this density indicates a $\mathrm{Nb}$ :Ta ratio between $2: 1$ and 3:1, according to data in Winchell and Winchell $(1951$, p. 96) and Palache and others, (1944, v. 1, p. 783).

\section{Corundum}

Corundum grains were found in nonmagnetic fractions of heavy-mineral samples and are characterized by a good basal parting visible even on rounded fragments. Gray and pink are the most common colors but yellow, blue, and white are found; and D = 3.84-4.09. Grains exhibit high relief $\left(\mathrm{N}_{\mathrm{e}}=1.77\right)$ and weak birefringence. The interference figure is normally uniaxial negative but anomalous biaxial figures were noted with (-)2V up to $10^{\circ}$. Corundum is length fast; the color in methylene iodide immersion mounts is slightly bluish; and crushed grains occasionally exhibit twinning. Spectroscopic tests show that a pink color is due to appreciable chromium. Blue corundum contains iron and titanium.

Corundum was found in nearly all the samples from Cape Mount County, especially in Mosaic Blocks C-14 and C-15. Pink to brown and gray translucent grains 2- 


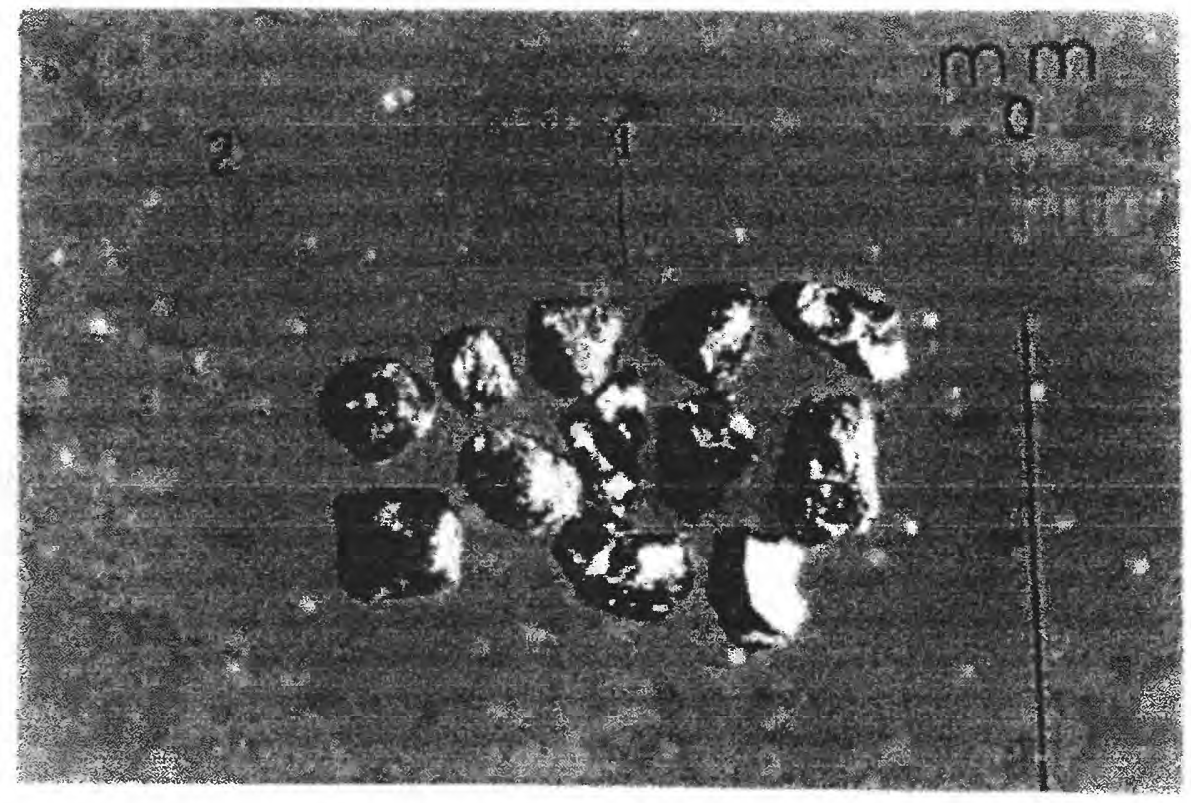

Figure 6. Chromite grains from northwestern Liberia 


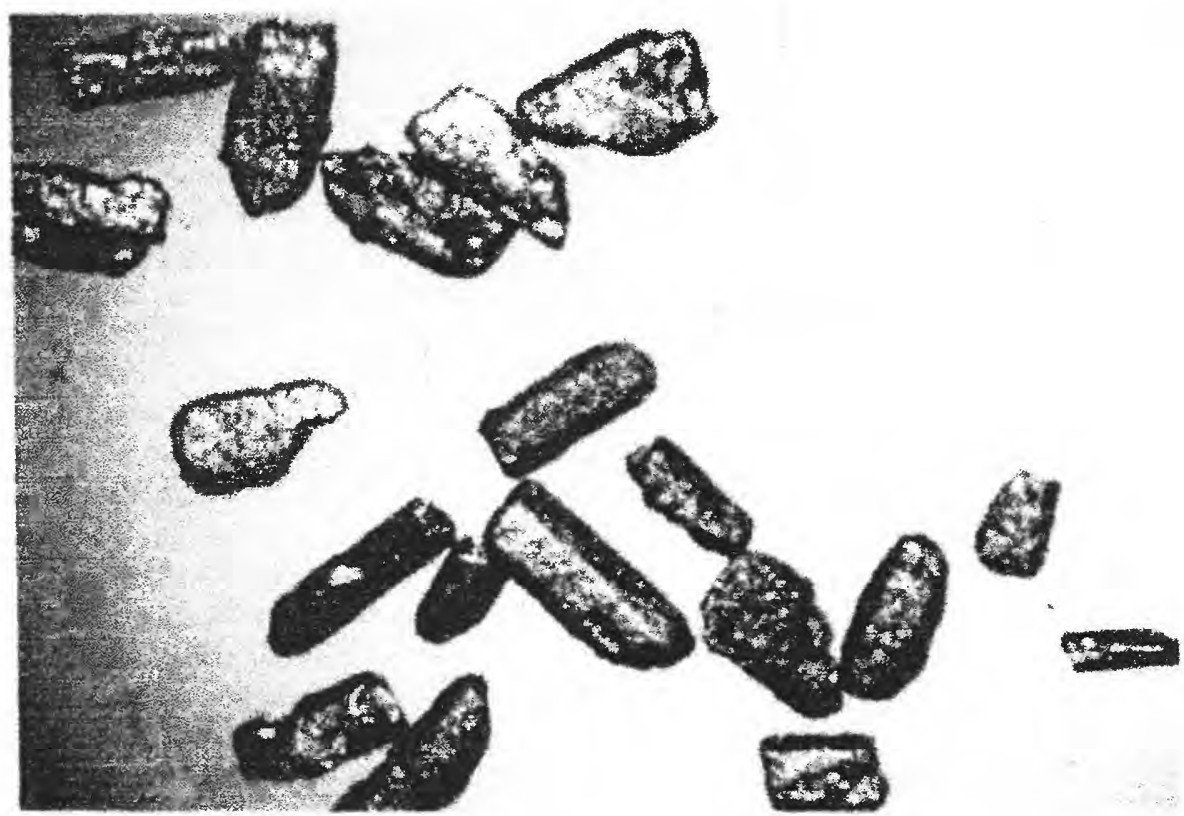

Figure 7. Columbite prisms from central Liberia 
$20 \mathrm{~mm}$ across are found by diamond miners in western Liberia who considered them as a guide to diamonds, but not an infallible one. Fragments of blue corundum up to $13 \mathrm{~cm}$ across were found in Mosaic Block E-16. Buff to gray alteration veining the blue corundum was shown by X-ray powder patterns to be diaspore, which may range up to 90 percent of some samples.

\section{Epidote}

Epidote (pistacite) grains are easily recognized by their distinctive light-greenishyellow color with weak pleochroism: $\mathrm{X}=$ colorless to pale yellow, $\mathrm{Y}=$ greenish yellow, and $\mathrm{Z}=$ yellowish green; strong birefringence, $\mathrm{N}_{\mathrm{x}}=1.72, \mathrm{~N}_{\mathrm{z}}=1.75 ;(-) 2 \mathrm{~V}=$ large, and strong dispersion $(\mathrm{r}<\mathrm{v})$. Most grains are irregular in shape, and optic-axis figures characteristically show isogyres that flare from the melatopes with brilliant green-purplered interference rings. Clinozoisite (iron-poor epidote) shows high relief, low birefringence, and an anomalous blue interference color. Epidote grains were found in almost all samples, and generally constituted a large proportion of the silicate minerals (Mosaic Blo10) .Piedmontite (manganese epidote) was noted in a few samples, and was recognized by its characteristic pleochroism: $\mathrm{X}=$ yellow, $\mathrm{Y}=$ purple, and $\mathrm{Z}=$ red, and the mean refractive index $=1.78$.

\section{Euxenite and fergusonite}

Euxenite and fergusonite, complex oxides of yttrium and niobium which occur typically in pegmatites, were identified in only a few samples from the Bomi Hills area (Mosaic Block E-16). Both occur as dark brown to black 1 to $2 \mathrm{~mm}$ equant grains with chonchoidal fracture, vitreous luster, and light-colored coatings. Both are isotropic due to metamictization. The density of euxenite is 4.98 ; that of fergusonite is about 5.5. The refractive index of detrital euxenite is about 2.06; that of fergusonite is about 2.08. Crushed grains of fergusonite are reddish brown; euxenite grains are brown.

Spectroscopic tests of fergusonite indicated major yttrium and nobium, and minor titanium and magnesium. Tantalum was not detected. Sodium fluoride bead tests showed that uranium is present in both minerals.

Identification was confirmed via X-ray powder patterns after heating to incandescence (Berman, 1955, p. 817, 819-820). After heating, both minerals became slightly to weakly anisotropic. The refractive index for euxenite increased to about 2.10, but that of fergusonite decreased to about 2.05. Not enough material was available to recheck the densities of the heated grains.

\section{Galena}

Galena is easily identified by its typical metallic lead-gray color, softness, and cubic form and cleavage. An unusual detrital mineral, it was first noted in a heavymineral sample from Mosaic Block J-3. A few heavy-mineral concentrates from the Tawalata area (Mosaic Block H-13) contained minute grains of galena. 


\section{Garnet}

Garnets are easily recognized by their pink to orange-red and red colors, vitreous luster, high relief, and isotropic character. Most of the grains are equant and angular to rounded. They exhibit irregular cracks and fractures, and some grains are coated with iron oxides. Two different varieties based on refractive index and specificgravity determinations were recognized: almandite: $\mathrm{N}=1.80-1.83 ; \mathrm{D}=4.18$, color pink to orange-red, and most abundant of the garnets in Liberia; and pyrope: $\mathrm{N}=1.73$ to 1.75 , $\mathrm{D}=3.73$, color deep red to blackish red in large grains but colorless to pale pink in crushed grains, and rare.

A chemical analysis of a pyrope concentrate showed in weight percent: $\mathrm{SiO}_{2} 40.6$; $\mathrm{Al}_{2} \mathrm{O}_{3} 22.4 ; \mathrm{Fe}_{2} \mathrm{O}_{3}$ 1.9; $\mathrm{FeO} 4.3 ; \mathrm{MgO} 20.0 ; \mathrm{CaO} 5.4 ; \mathrm{Na}_{2} \mathrm{O} 0.45 ; \mathrm{K}_{2} \mathrm{O} 0.13 ; \mathrm{H}_{2} \mathrm{O}^{-} 0.00$; $\mathrm{H}_{2} \mathrm{O}^{+} 0.18 ; \mathrm{TiO}_{2} 0.34 ; \mathrm{P}_{2} \mathrm{O}_{5} 0.18 ; \mathrm{MnO} 0.14 ; \mathrm{CO}_{2} 0.05=96.0$. This analysis is closely comparable with a pyrope analysis in Deer and others $(1962$, v. 1, p. 97) which is considered among the richest in pyrope molecule recorded. A spectrochemical check of this sample indicated unusual chromium content $\left(\mathrm{Cr}_{2} \mathrm{O}_{3}=4\right.$ percent). Pyrope is the typical garnet in kimberlites; and chrome pyrope inclusions with 8 tol0 percent $\mathrm{Cr}_{2} \mathrm{O}_{3}$ in natural diamond were reported by Meyer (1968).

\section{Gold}

Gold is readily recognized under the binocular microscope by its distinctive metallic golden yellow color, and malleability. It usually occurs in the form of thin flakes or rounded, elongate to equant grains (see fig. 8). Placer deposits are known in Cape Mount, Grand Gedeh, and Sinoe Counties.

\section{Gorceixite}

This rare phosphate of barium and aluminum was found as well-rounded blackcoated pebbles up to $8 \mathrm{~mm}$ long in diamond-bearing gravels in the Kakata area (Mosaic Blocks $\mathrm{H}-20$ and I-20). The mineral is white to buff, microcrystalline, with mass refractive index about 1.625 and density about 3.2. Similar material is found in diamond sands in Ghana, Sierra Leone, Rodesia (Palache and others, 1944, v.2, p. 822) and in Minas Gerais, Brazil (Ford, 1932, p. 711), where pebbles are called "favas", alluding to its association with diamond.

\section{Hornblende}

Hornblende has a characteristic slender prismatic form, green color, and marked pleochroism: $X=$ pale green, $Y=$ yellow green, $Z=$ medium to dark green $(X<Y<Z)$. Hornblende has moderate relief $\left(\mathrm{N}_{\mathrm{z}}=1.65\right.$ to 1.68$)$ and birefringence and is length slow. $\mathrm{Z}: \mathrm{c}=18^{\circ}$ to $25^{\circ}$, and $(-) 2 \mathrm{~V}=60^{\circ}$. Green hornblende is found in most samples, and it ranges from rare to abundant. It usually occurs as columnar grains with perfect prismatic cleavages and frayed ends. 


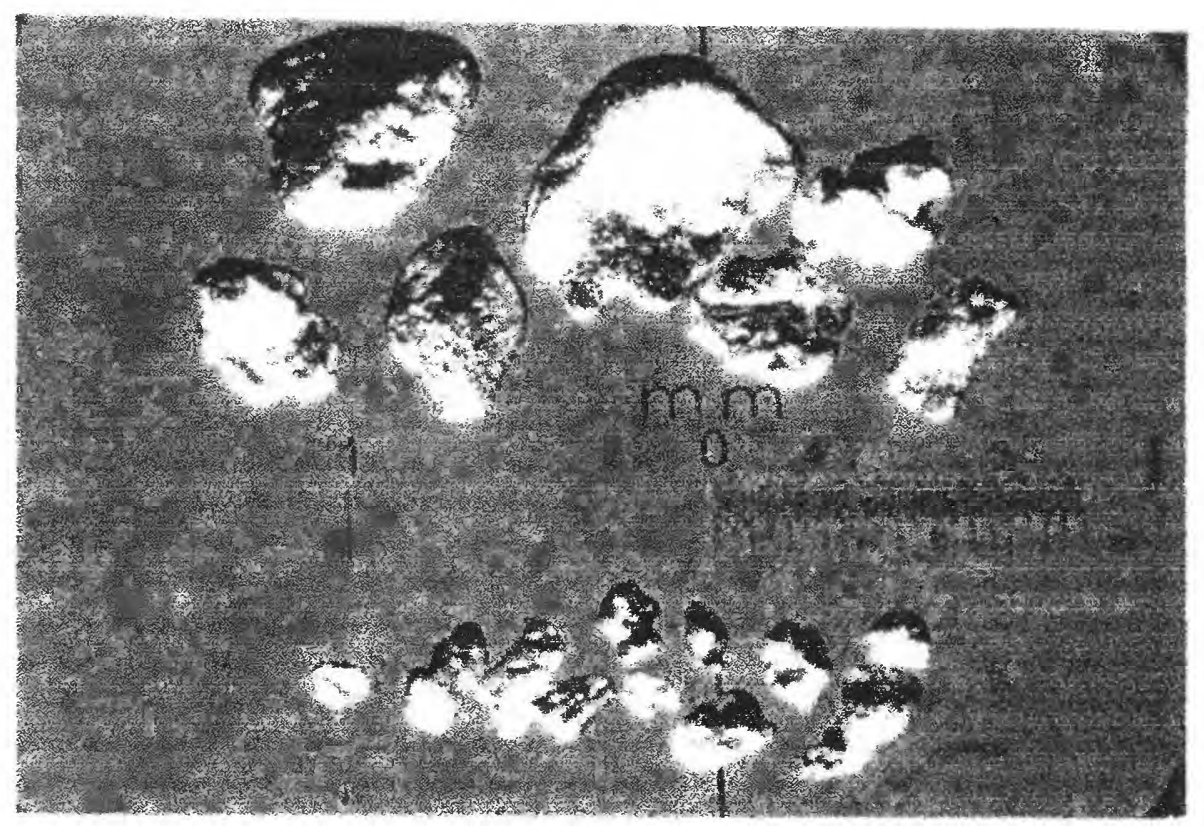

Figure 8: Grains of gold in northern Liberia placers 


\section{Hypersthene}

Hypersthene grains are identified by slender to short prismatic form, parallel extinction, and chracteristic pleochroism: $X=$ pale pink or red, $Y=$ pale yellow, $Z=$ pale green. The refractive index $N_{z}=1.70$, birefringence is low, elongation is slow, and $(-) 2 \mathrm{~V}=$ large. Many grains contain numerous minute black inclusions, presumably ilmenite or magnetite. Hypersthene is derived from granulitic rocks mainly; but some comes from norite bodies similar to the one that underlies Cape Mount at Robertsport (Mosaic Block B-18).

A deep-colored variety of another orthopyroxene is identified as eulite based on $\mathrm{D}$ $=3.81$ to $3.83, \mathrm{X}=$ yellow brown, $\mathrm{Y}=$ pale yellow, and $\mathrm{Z}=$ dull green, $\mathrm{Z}>\mathrm{X}>\mathrm{Y}, \mathrm{N}_{\mathrm{x}}=$ $1.745, \mathrm{~N}_{\mathrm{y}}=1.755, \mathrm{~N}_{\mathrm{z}}=1.764,(-) 2 \mathrm{~V}=85^{\circ}$ to $89^{\circ}$, and strong dispersion $(\mathrm{r}<\mathrm{v})$. Eulitebearing rocks are found in a narrow belt in central Liberia (Mosaic Block R-15) associated with layered hypersthene-plagioclase gneiss and quartzofeldspathic gneiss (E. R. Force, written commun., 1971).

\section{Ilmenite}

Ilmenite grains are generally concentrated in the most magnetic fraction from the Frantz separator. The dark grains are commonly subrounded, show characteristic purplegray to black colors, pitchy and submetallic lusters under the stereomicroscope, and pits are filled with white to rusty leucoxene. Crushed grains in transmitted light are usually opaque. A magnesium-bearing variety, picroilmenite, occurs in the Komgba area (Mosaic Block F-11). This variety is slightly translucent brown on thin edges, has high refractive index, but low birefringence. It shows a wide range of magnetic susceptibility from weakly ferromagnetic to moderately paramagenetic (see table 1).

Chemical analyses of three ilmenites showed titania ranging from 21 to 48 percent and total iron oxides from 73 to 44 percent. Apparently the ilmenite is intergrown with hematite and magnetite as normally iron-rich ilmenite (critchtonite) averages about 50 percent $\mathrm{TiO}_{2}$ and 50 percent total iron oxides. One sample of picroilmenite contained 9.2 percent $\mathrm{MgO}$. Spectrochemical analysis of the 4 samples showed unusual amounts of chromium ( 700 to $30,000 \mathrm{ppm}$ ), vanadium (300 to $700 \mathrm{ppm}$ ), and zirconium (200 to $500 \mathrm{ppm}$ ), and apparently anomalous nickel (500 ppm).

Ilmenite is abundant to predominant in all the samples and has wide range of distribution. In beach sands, ilmenite constitutes $10-89$ percent of the heavy minerals. Subhedral to rounded grains up to $2 \mathrm{~cm}$ across are found in a number of streams in western Liberia, especially in Mosaic Blocks H-12, H-13, I-12, and I-13.

\section{Kyanite}

Kyanite grains under the binocular microscope are readily recognized by their characteristic light-blue color and platy form (see fig. 9) with right-angle cleavages (100 and (00I). Green and yellow grains are relatively scarce. In transmitted light the mineral shows inclined extinction on (100), Z:c $=29^{\circ}$ to $31^{\circ}$, moderate relief and low birefringence, $\mathrm{N}_{\mathrm{z}}=1.73$, and (-)2V = large. Chemical analyses of four samples from Grand Bassa County showed that the mineral meets minimum specifications for use as high-grade refractory material (Stanin and Cooper, 1968; Rosenblum 1968). Spectrographic analyses indicated anomalous amounts of chromium (200 to $300 \mathrm{ppm}$ ), cerium (300 to $700 \mathrm{ppm}$ ), lanthanum ( 70 to $500 \mathrm{ppm}$ ), and neodymium (up to $300 \mathrm{ppm}$ ). 


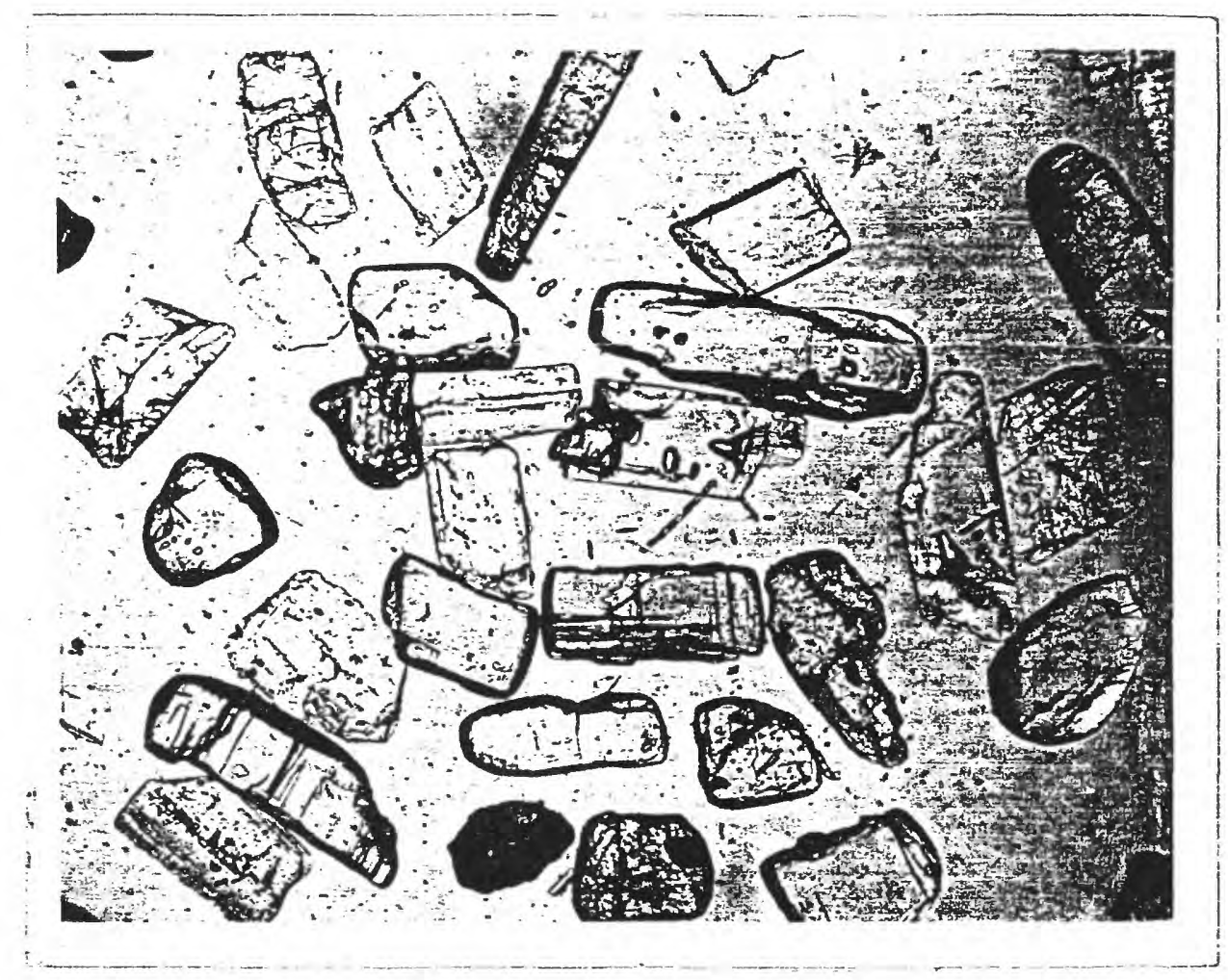

Figure 9. Kyanite and sillimanite grains. Refractive index of immersion oil is 1.67 ; magnification is about $80 \mathrm{x}$. 


\section{Monazite}

Monazite grains are recognized by their characteristic well-rounded egg-shaped to kidney-shaped forms (see fig. 10) and pale-yellow to yellow-brown color. Some grains exhibit a brown to reddish-brown color, which may be due in part to alteration or iron staining. Grains occasionally show perfect (001) cleavage and extinction angles to this plane ranging from $2^{0}$ to $10^{\circ}$, birefringence is strong and relief high $\left(\mathrm{N}_{\mathrm{x}}=1.79, \mathrm{~N}_{\mathrm{z}}=\right.$ 1.84), $(+) 2 \mathrm{~V}$ ranges from $2^{\circ}$ to $10^{\circ}$, dispersion is strong $(\mathrm{r}<\mathrm{v})$, and fluorescence under unfiltered ultraviolet light is strong yellowish green.

$\mathrm{X}$-ray fluorescence analysis of 11 monazites including 7 from beach samples were averaged as follows (in percent): $\mathrm{La}_{2} \mathrm{O}_{3} 14.76 ; \mathrm{Ce}_{2} \mathrm{O}_{3} 29.8 ; \mathrm{Pr}_{2} \mathrm{O}_{3} 2.55 ; \mathrm{Nd}_{2} \mathrm{O}_{3}$ 9.5; $\mathrm{Sm}_{2} \mathrm{O}_{3}$ 1.3; $\mathrm{Eu}_{2} \mathrm{O}_{3} 0.11 ; \mathrm{Gd}_{2} \mathrm{O}_{3} 0.7 ; \mathrm{Tb}_{2} \mathrm{O}_{3} 0.07 ; \mathrm{Dy}_{2} \mathrm{O}_{3} 0.2 ; \mathrm{Ho}_{2} \mathrm{O}_{3}<0.07 ; \mathrm{Er}_{2} \mathrm{O}_{3} 0.06 ; \mathrm{Tm}_{2} \mathrm{O}_{3}$ $<0.04 ; \mathrm{Yb}_{2} \mathrm{O}_{3}<0.03 ; \mathrm{Lu}_{2} \mathrm{O}_{3}<0.05 ; \mathrm{Y}_{2} \mathrm{O}_{3} 0.8$; and $\mathrm{ThO}_{2}$ 7.2.

Monazite grains were found in almost all the samples. High concentrations were noted in many samples from the Bopolu and Voinjama areas.

\section{Muscovite}

Muscovite occurs as thin platy grains. They are invariably rounded with irregular margins and show characteristic low refractive index $\left(\mathrm{N}_{\mathrm{z}}=1.58\right)$. Birefringence is strong, $(-) 2 \mathrm{~V}=30^{\circ}$ to $40^{\circ}$, dispersion distinct $(\mathrm{r}>\mathrm{v})$, inclusions are usually iron oxides, and accessory minerals include zircon, rutile, and apatite.

\section{Pyrite and marcasite}

Pyrite is recognized by its characteristic brass-yellow color, and cubic and dodecahedral forms, its hardness (5), and it crushes to a black powder. Because the mineral is nonmagnetic, it is found in the least magnetic fractions. Pyrite was observed in several samples from Mosaic Blocks E-16 and H-13.

Marcasite, the dimorph of pyrite, occurs as minute spherical aggregates of microscopic grains in only two samples, both from Mosaic Blocks B-17 and B-18. The mineral is recognized by its form, luster, relative softness, and positive tests for iron and sulfur. Also, melanterite $\left(\mathrm{FeSO}_{4} .7 \mathrm{H}_{2} \mathrm{O}\right)$ is seen in the same samples and apparently develops during storage, upon oxidation of the marcasite.

\section{$\underline{\text { Riebeckite }}$}

Riebeckite occured in only three samples from Mosaic Blocks D-11 and D-12; because of its rarity it is not included in table 2. The colors of 2 types of riebeckite are distinctive: $\mathrm{X}$ in both is blue, $\mathrm{Y}$ is yellow or violet, and $\mathrm{Z}$ is purple or yellow, respectively; and the absorption schemes of these two riebeckites are: $\mathrm{X}=\mathrm{Z}>\mathrm{Y}$; and $\mathrm{X}$ $>\mathrm{Y}>\mathrm{Z} . \mathrm{N}_{\mathrm{x}}=1.68$, and $N_{\mathrm{z}}=1.69$. The mineral is undoubtedly derived from massive sodic granodiorite in the area which contains 5-10 percent riebeckite. 


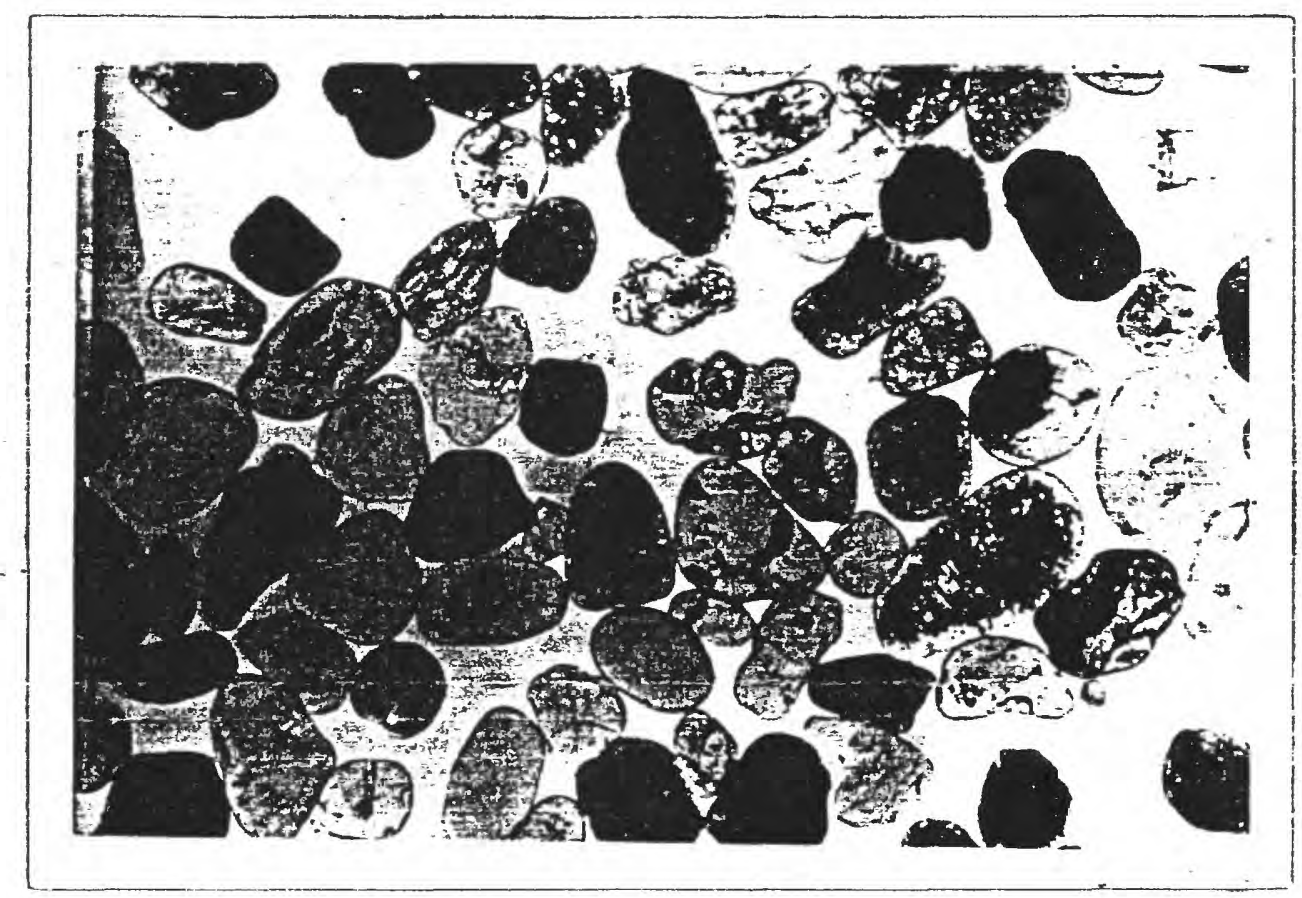

Figure 10. Monazite concentrate. Refractive index of immersion oil is 1.74; magnification is about $50 \mathrm{x}$. 


\section{Rutile}

Rutile crystals were readily recognized by their typical resinous to adamantine luster. Red rutiles are only rarely observed. The more common ferriferous type shows various shades of brown to black. The crystals are usually striated and some tetragonal prisms exhibit elbow-type twinning (see fig. 11a). The mineral is characterized by extreme relief and birefringence and parallel extinction. It is uniaxial positive and the density of the common variety ranges from 4.26 to 4.58 . Spectrochemical analysis of two samples showed chromium 100-300 ppm, iron 1,500 ppm, niobium 200-300 ppm, scandium and yttrium $50 \mathrm{ppm}$ each, and vanadium $300-700 \mathrm{ppm}$. Minor zirconium and silica were without doubt due to impurities.

\section{Siderite}

Siderite grains are found in samples from Mosaic Block K-6 in uncommon prismatic habit. The crystals are doubly terminated by rhombohedral faces similar to the nailhead variety of calcite (see fig. 12), and X-twins are common. The grains are greenish yellow to yellow-brown and are extracted with ilmenite at 0.4 ampere setting on the magnetic separator. The refractive index is very high $\left(\mathrm{N}_{\mathrm{e}}=1.64, \mathrm{~N}_{\mathrm{o}}=1.85\right)$, and birefringence is extreme $(0.21)$. The mineral shows extinction parallel to the prisms, and is uniaxial negative. On heating to redness, the mineral turns black and ferromagnetic.

\section{Sillimanite}

Sillimanite grains are easily recognized by their slender prismatic habit (see fig. 13). The grains are usually colorless, have irregular terminations, and good (010) cleavage. Normally sillimanite is found in the nonmagnetic fractions of the heavy minerals. It shows moderate relief and birefringence, $\mathrm{N}_{\mathrm{x}}=1.66, \mathrm{~N}_{\mathrm{z}}=1.68,(+) 2 \mathrm{~V}=25^{\circ}$ $30^{\circ}$ (unusually small angles, ranging from $4^{0}$ to $17^{0}$, have been measured in some grains), the dispersion is strong $(r>v)$, and the extinction is parallel to the prisms. Sillimanite commonly occurs in samples from Grand Cape Mount County.

\section{Spinel}

Spinels are readily recognized by high refractive indices, distinctive colors, and isotropy. The grains are generally well rounded and considerably pitted with characteristic conchoidal fracture. Shades of brown and green are commonly associated with indices from 1.80 to 1.84 . Positive microchemical tests for iron indicate ferroan varieties such as ceylonite and hercynite. Generally these are extracted on the Frantz separator between .5 and 1.0 ampere settings, higher than for the iron garnets.

\section{Staurolite}

Staurolite grains have a typically reddish-orange color, are usually irregular in shape, show conchoidal fracture and (010) cleavage, and have many rounded inclusions of minerals and brown-black carbonaceous material (?) (see fig. 14). Pleochroism at standard thickness is distinctive: $\mathrm{X}=$ colorless or pale yellow, $\mathrm{Y}=$ yellow, $\mathrm{Z}=$ golden yellow. The refractive index is fairly high $\left(\mathrm{N}_{\mathrm{z}}=1.75\right)$, birefringence is moderate to low, extinction is parallel, $(+) 2 \mathrm{~V}=$ about $80^{\circ}$, and dispersion is distinct, $(\mathrm{r}>\mathrm{v})$. Like sillimanite, staurolite is common in samples from Grand Cape Mount County. 


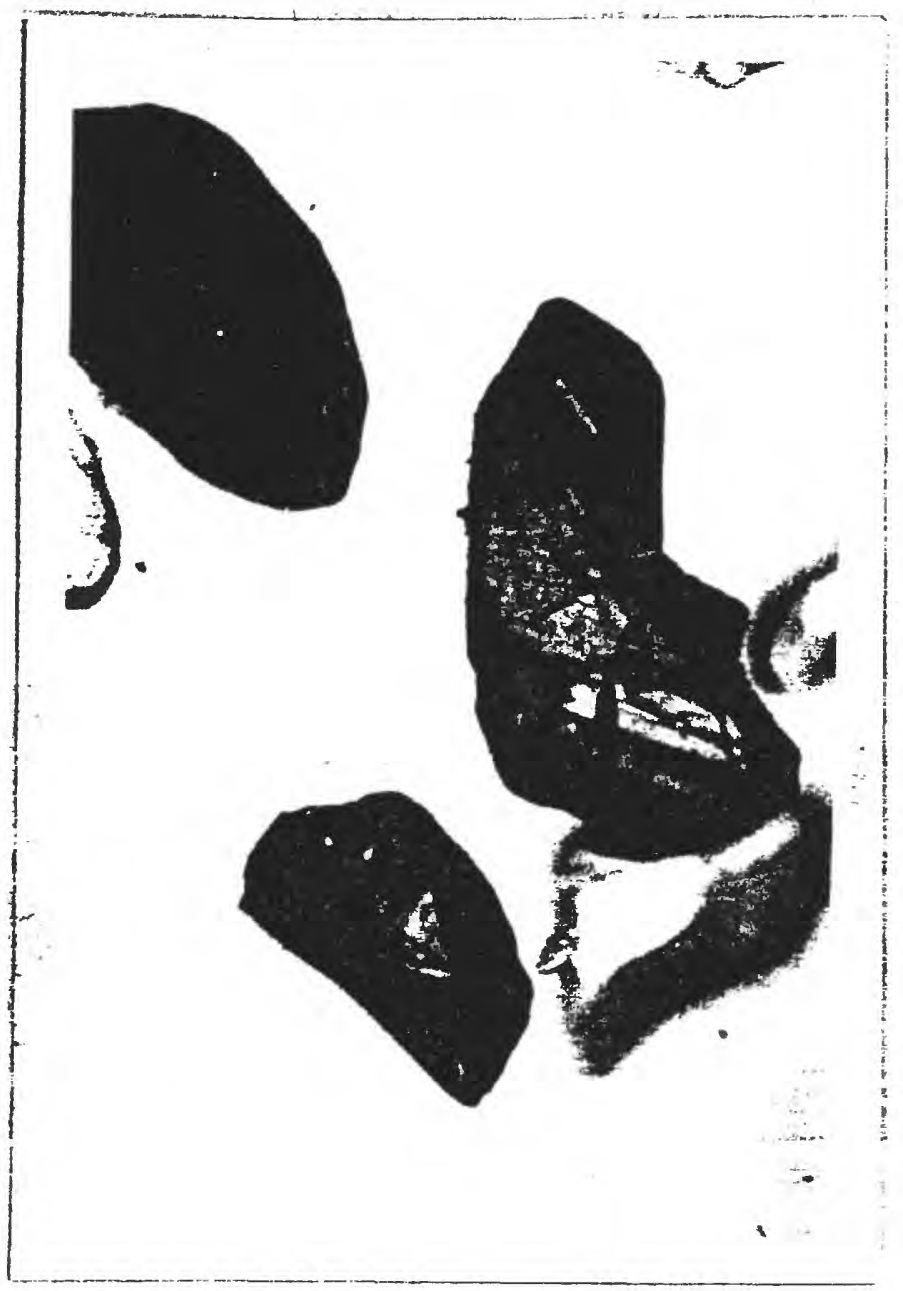

$a$

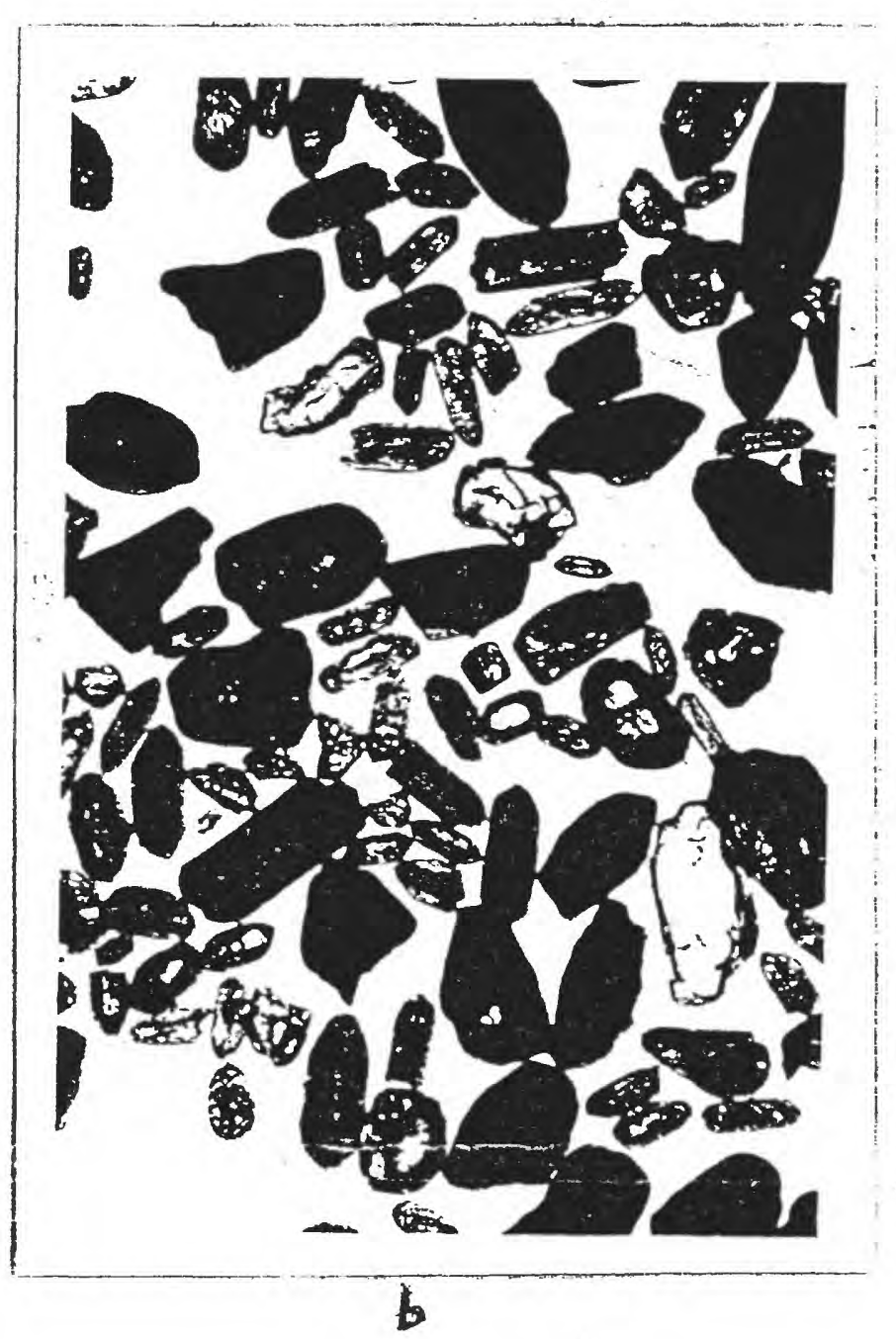

Figure 11. Rutile: (a) knee-shaped grains; (b) rutile and zircon concentrate. Refractive index of immersion oil is 1.74 ; magnification of (a) is about $120 \mathrm{x},(\mathrm{b})$ is about $40 \mathrm{x}$. 


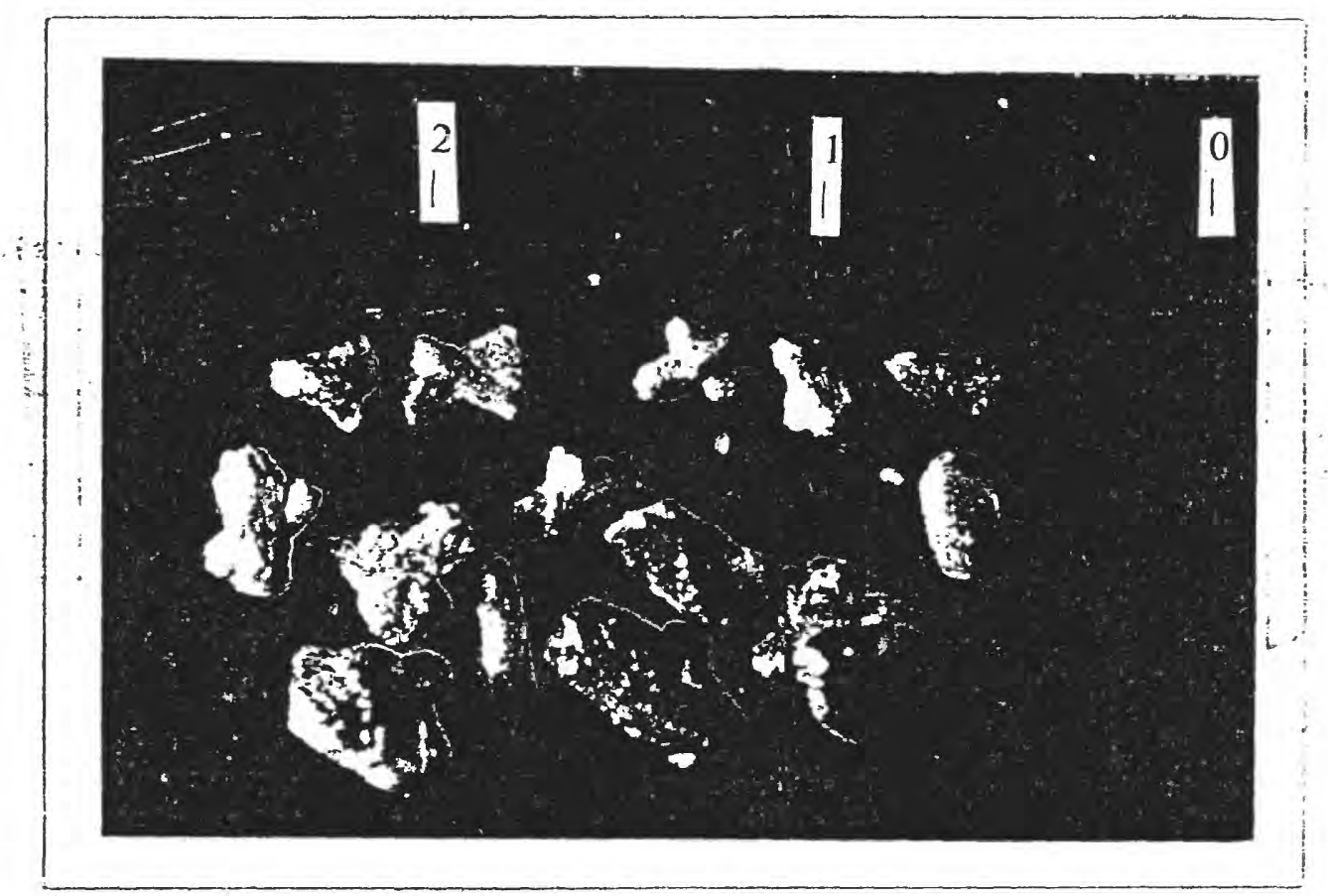

Figure 12. Siderite crystals (scale in millimeters). 


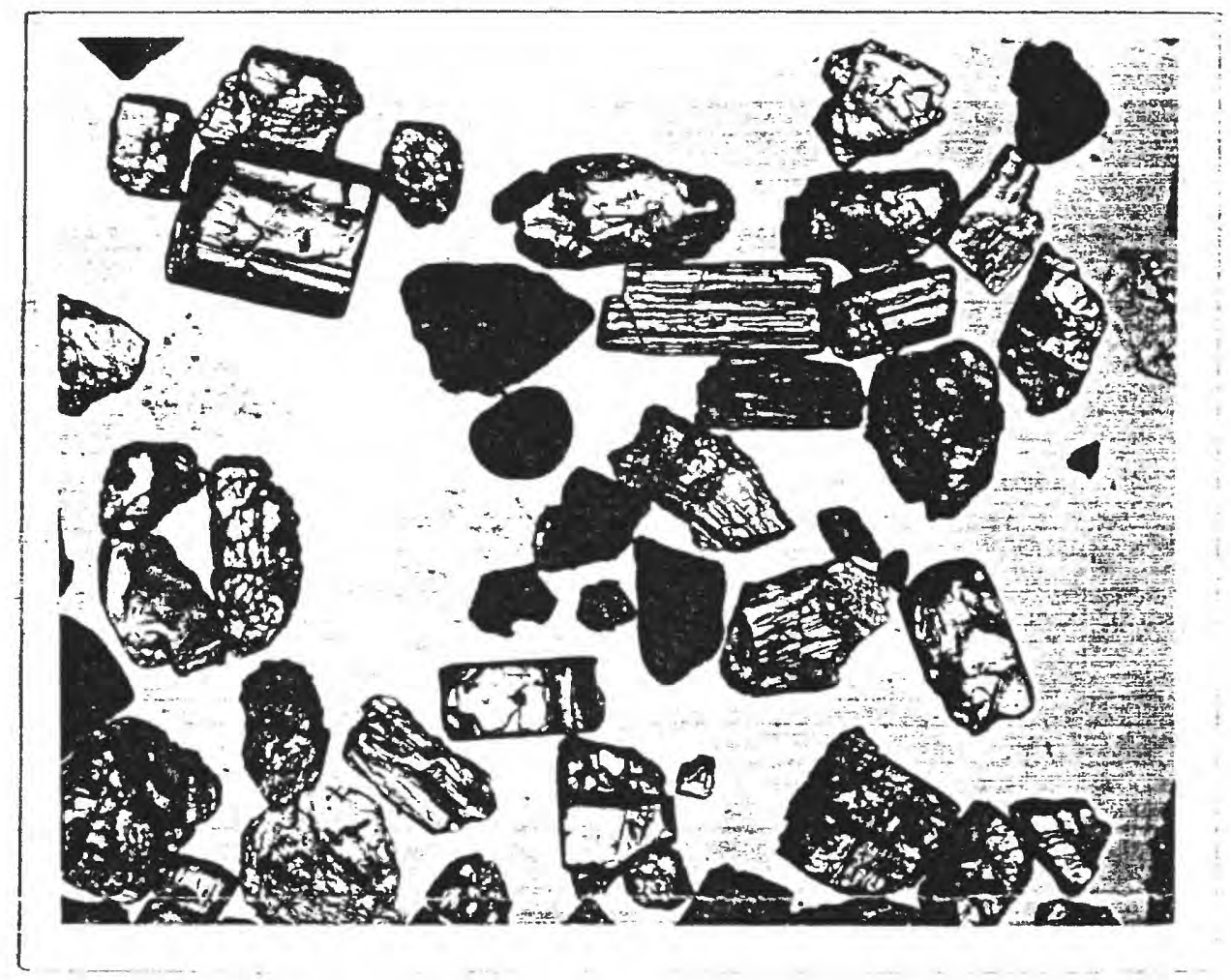

Figure 13. Sillimanite concentrate. Dark minerals are hornblende and rutile. Quartz has little relief. Refractive index of immersion oil is 1.54 ; magnification is about $80 \mathrm{x}$. 


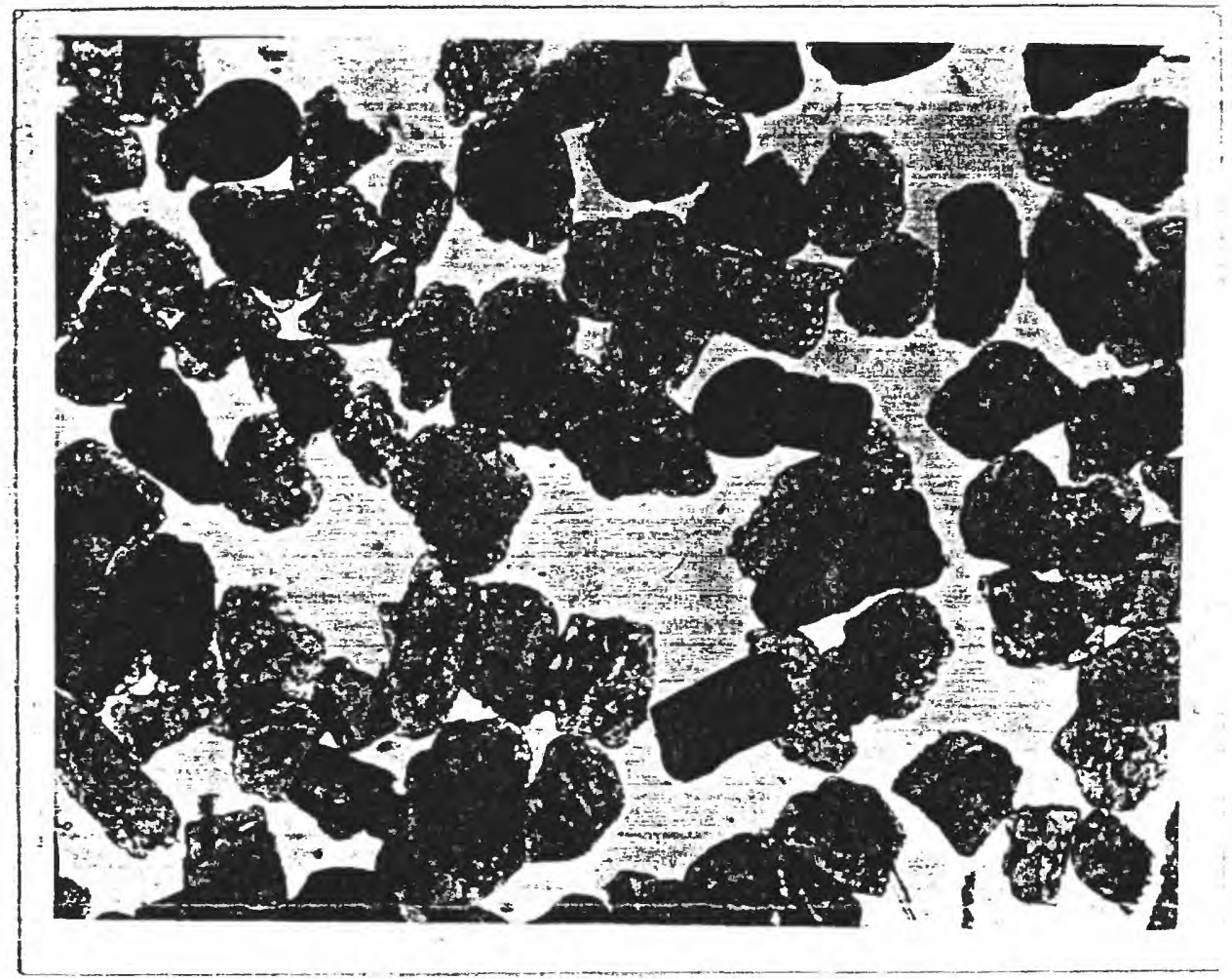

Figure 14. Staurolite concentrate. Black minerals include tourmaline, hornblende, and limonite. Refractive index of immersion oil is 1.74; magnification is about $80 \mathrm{x}$. 


\section{Tourmaline}

Tourmaline (schorlite) crystals are commonly short, stubby prisms with rhombohedral terminations at one end. Basal to semibasal, irregularly rounded grains are also observed. The color is generally brown but green or greenish-blue colors were noted. Tourmaline grains may be recognized by their characteristic strong dichroism with maximum absorption perpendicular to the prism (see fig. 15). Relief is moderate, $\left(\mathrm{N}_{\mathrm{e}}=\right.$ $1.64, \mathrm{~N}_{\mathrm{o}}=1.67$ ), birefringence is strong, and the fast ray is parallel to the prism. Normally uniaxial and negative, it is occasionally biaxial with maximum $(-) 2 \mathrm{~V}=10^{\circ}$.

\section{Xenotime}

Xenotime usually occurred as well-developed tetragonal bipyramids, with some short prism faces (see fig. 16a), and in immersion oil appears as rounded square to elongate grains with numerous inclusions (fig. 16b). The grains are usually brown to reddish brown and yellow-brown, and a light gray color may be due to alteration. Xenotime is recognized by its variable high relief $\left(\mathrm{N}_{\mathrm{o}}=1.72, \mathrm{~N}_{\mathrm{e}}=1.81\right)$ and strong birefringence. It is uniaxial positive, length slow, shows weak pleochroism, parallel extinction, and $\mathrm{D}=4.41$ to 4.61 .

Spectrochemical analysis of a sample showed, in ppm: barium 100, cobalt 200 , lead 3,000 , uranium 3,000 , zirconium 1,500 , thorium 20,000 , ytterbium 2,000 , gadolinium 20,000 , dysprosium 15,000 , holmium over 1,800 , erbium 20,000 , thulium over 1,800 , and lutetium over 1,800 . Xenotime grains were noted in almost all samples; however, the average content is below 1 percent.

\section{Zircon}

Zircon grains are easily recognized by their characteristic tetragonal crystal habit (see fig. 17). Commonly the grains are colorless to pale gray or brown, and crystals are prismatic with (110) and/or (100) forms, and double-pyramid terminations. Basal (001) plates were observed in a number of samples but are not abundant. Generally the grains are fractured and showed a small amount of rounding, $D=4.6$ to 4.70 , refractive indices are very high $\left(\mathrm{N}_{\mathrm{e}}=1.96, \mathrm{~N}_{\mathrm{o}}=1.92\right)$, birefringence is strong, and the length is slow. Zircon is uniaxial positive, shows parallel extinction, zoning is often observed, and inclusions are common. Clear colorless grains fluoresce bright golden-orange under short-wave UV light, but fluorescence of colored grains is weak to nil. Zircon was found in every sample and is considered one of the most ubiquitous minerals; usually it constitutes 10 to 20 percent of the heavy minerals.

A completely metamict variety of zircon (malacon) was seen only in samples from Mosaic Block F-11. Metamict zircons are grayish green to grayish brown in color, translucent, with density ranging from 3.90 to 4.02 . The relief is very high $\left(\mathrm{N}_{\mathrm{e}}=1.85, \mathrm{~N}_{\mathrm{o}}\right.$ $=1.84$ ) but the birefringence is weak. The presence of uranium was confirmed by a sodium fluoride bead test. Radioactivity of a 1-gram concentrate is strong enough to be measured on the most sensitive scale of a Geiger counter. 


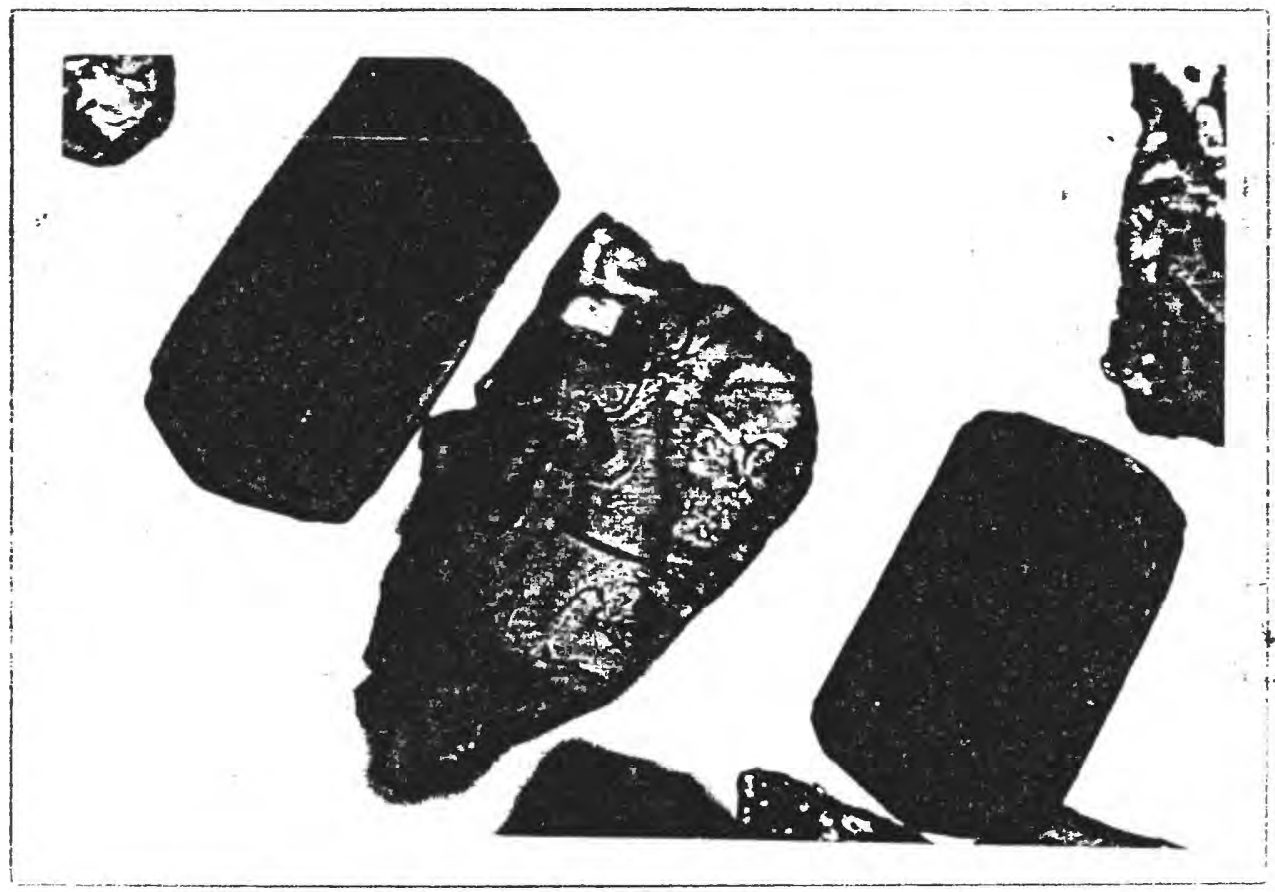

Figure 15. Tourmaline prisms with aligned inclusions. Refractive index of immersion oil is 1.54; magnification is about $120 \mathrm{x}$. 


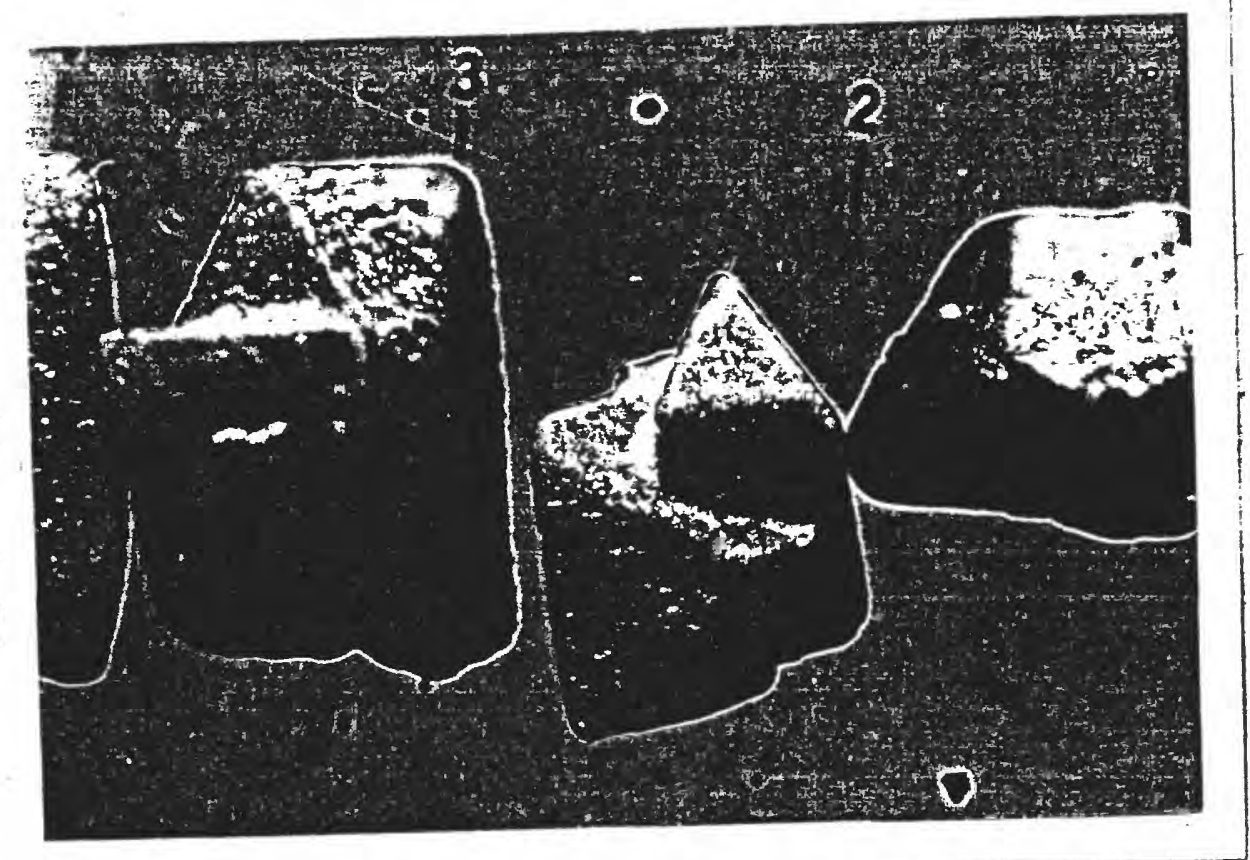

a.

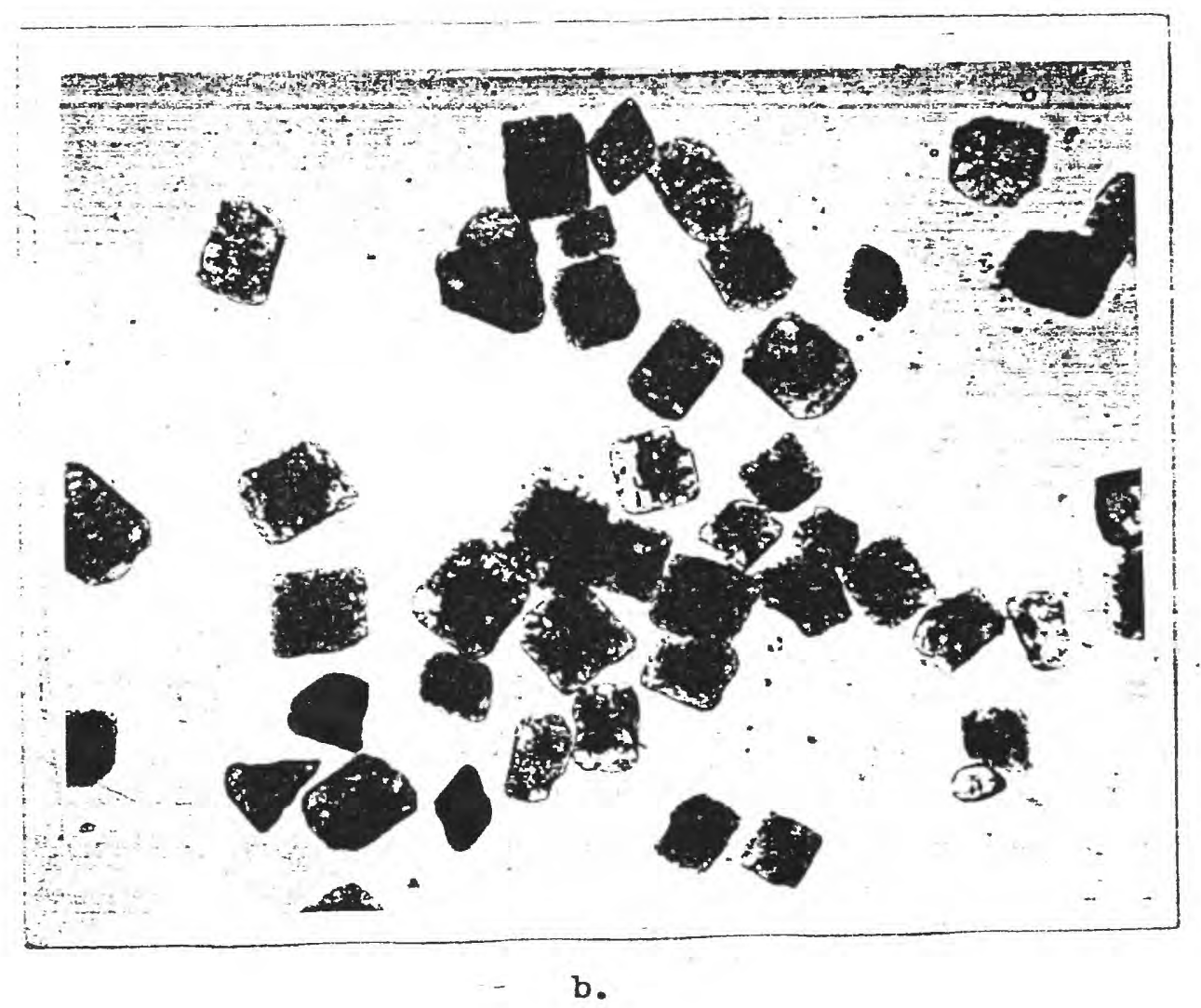

Figure 16. Xenotime: (a) bipyramids (scale in millimeters); (b) crystals turbid with submicron-sized black inclusions. Refractive index of immersion oil is 1.74; magnification is about $80 \mathrm{x}$. 


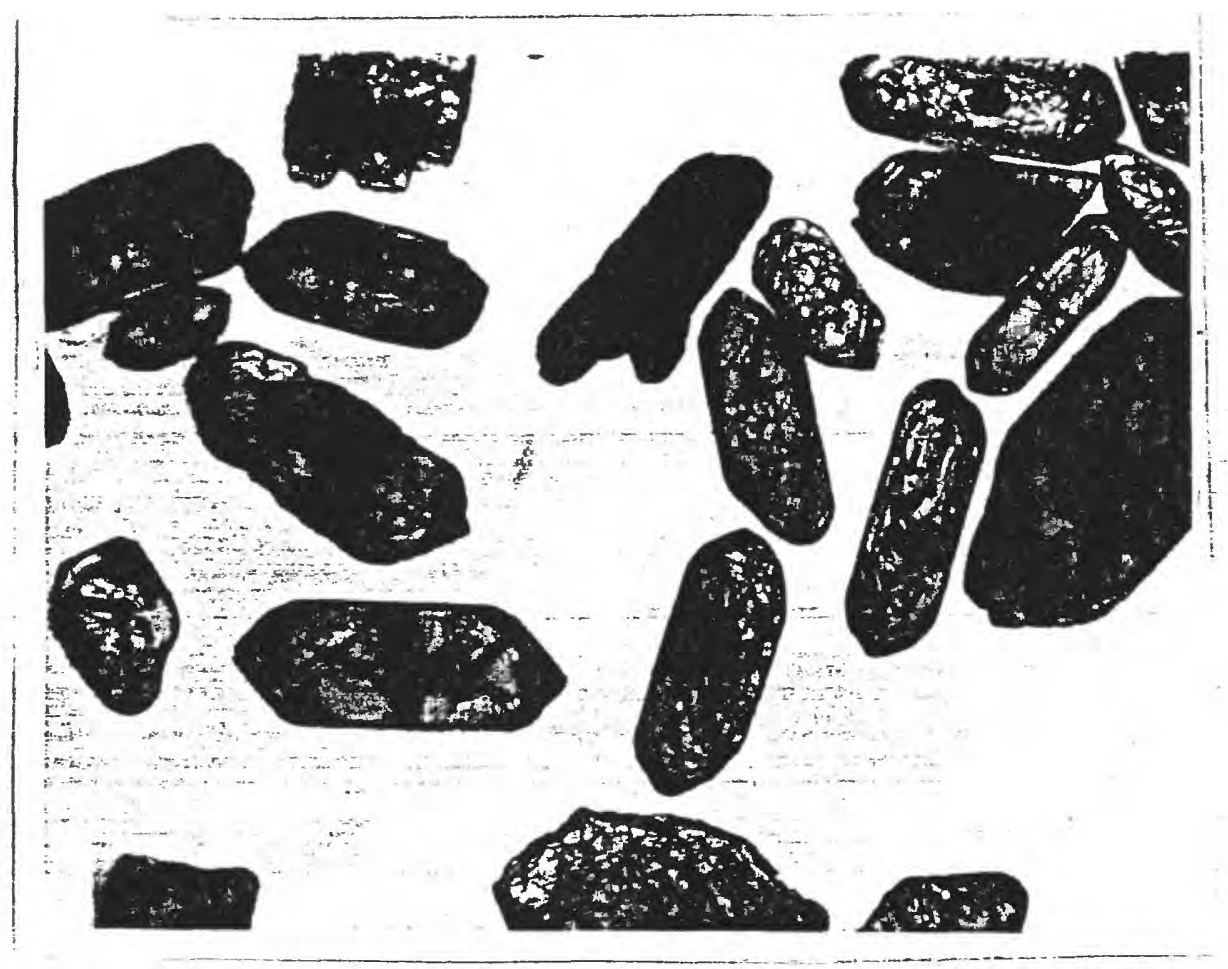

Figure 17. Zircon grains. Refractive index of immersion oil is 1.74; magnification is about $80 \mathrm{x}$. 
Spectrographic analyses of concentrates of two normal zircons showed in ppm: uranium (not detected), thorium 100 to 150 , hafnium 1500 to 2000 , yttrium 700 to 7000 , manganese 200 to 300 , niobium 20, lead 100 , scandium 100 to 200 , ytterbium 70 to 200 , and tin 30 .

Spectrographic analysis of a metamict zircon concentrate showed, in ppm: uranium 3,000 , thorium 2,000 , hafnium 5,000 , yttrium, 5,000 , manganese 1,000 , niobium 2,000 , lead 700 , scandium 150 , ytterbium 400 , thulium 150 , and lutetium 300 . In addition it had 4.76 percent $\mathrm{H}_{2} \mathrm{O}$.

\section{Zoisite}

Zoisite grains typically have colorless and irregular forms, with perfect cleavage in one direction (010). Relief is high $\left(\mathrm{N}_{\mathrm{x}}=1.69\right.$ to 1.70$)$, and birefrigence is low $(0.01)$. Grains showed length-fast orientation and parallel extinction. Acute-bisectrix orientations show characteristic deep-blue anomalous interference colors with strong dispersion $(\mathrm{r}<\mathrm{v}),(+) 2 \mathrm{~V}=0^{\circ}$ to $30^{\circ}$. According to the size and orientation of the optical axial angle, both alpha and beta zoisites are present (Winchell and Winchell, 1951, p. 446). Zoisite grains occur in samples from the Grand Bassa area and Grand Cape Mount County.

\section{GEOLOGY OF SOURCE TERRANES}

The Precambrian geology of western Liberia is described in White and Leo (1969) and White (1969). Tysdal and Thorman (1983) published the only geologic map of Liberia. The widest-spread and apparently oldest rock unit in Liberia is polymetamorphic quartzo-feldspathic gneiss which ranges in character from massive with relict igneous texture to well-foliated gneiss showing relict sedimentary texture. The grade of metamorphism is generally medium to high amphibolite-facies, but a 30-kmwide belt of granulite-facies rocks occurs along the western coast of Liberia, and is separated from amphibolite-facies rocks by mylonitic gneiss. In the granulite-facies belt, orthopyroxene gneiss is most common, with or without clinopyroxene, and is referred to as mafic granulite. Those rocks with less than about 30 percent mafic minerals are referred to as felsic granulite. Granulite-facies rocks also occur locally in north-central Liberia.

In central Liberia, migmatite consists of granitic rock pervading foliated hornblende gneiss, biotite gneiss and amphibolite. In addition to the gneiss and migmatite, layered amphibolite, quartzite, schist, iron-formation, and some manganeseformation underlie large areas. Small ultramafic bodies are now largely altered to serpentinite and talc-tremolite-chlorite schist. Overlying iron-formation and associated metasedimentary rocks are preserved in complex synclines in several narrow mountain ranges of the country. 
Several small granitic plutons intrude the gneissic and schistose rocks. These range in composition from granite to quartz diorite, and locally show weak foliation. Other small intrusives include granitic pegmatite, charnockite, trondhjemite, and kimberlite, all of which were similarly subjected to regional metamorphism. Many Jurassic tholeiitic and noritic diabase dikes trend northwest across the Precambrian terrane from Ivory Coast to Sierra Leone. Gabbro and norite plugs and dikes, probably of the same age as the diabase, are partly uralitized. Paleozoic (?) to Cretaceous sedimentary rocks comprising conglomerate, sandstone, and shale crop out along the coast between Monrovia and Buchanan (White, 1969). Finally, white lagoonal sands of Recent age cover large areas along the coast between Robertsport and Greenville.

As part of the West African shield area, the Liberian terrane is undergoing peneplanation under rigorous tropical conditions of abundant seasonal rainfall and yearround high temperatures. The laterite-saprolite zone is as much as $20 \mathrm{~m}$ thick, but averages 5 to $6 \mathrm{~m}$ in most parts of Liberia. The land surface slopes gradually, about 2 to $3 \mathrm{~m}$ per $\mathrm{km}$, from the Guinea border on the northeast to the Atlantic Ocean on the southwest. Erosion-resistant outcrops of iron-formation and diabase and gabbro plugs and dikes project above the peneplain. The major streams generally are incised into the laterite cover about 5 to $6 \mathrm{~m}$, and have rocky courses for much of their lengths. There are few falls, many rapids, no flood plains, and few river terraces. Braided channels are common but these, like the many meander-like bends, are founded on rock structures rather than formed by erosional-depositional processes on flood-plains. During the dry season, the major streams are sluggish and many braided channels dry up; during the rainy season, large volumes of muddy water are discharged and local river sediments are removed and deposited downstream by the end of the season. Under these conditions, most heavy minerals in the streams and in beach sands are apparently one-cycle types and their characteristics and abundances reflect their relative stabilities in the weathering profile.

\section{SOURCES OF POTENTIALLY COMMERCIAL MINERALS}

Economic or potentially commercial minerals in the samples studied include, in generally decreasing order of abundance: ilmenite, zircon, rutile, magnetite, monazite, aluminum silicates, corundum, gold, chromite, and cassiterite. Genetic relations among these minerals are not apparent, but associations of each with the major rock types is indicated below. Headwater sampling is required to best show specific genetic relations. However, this has been done only incidentally for a few of the heavy minerals such as ilmenite, gold, chromite, and aluminum silicate minerals.

Major sources of ilmenite are undoubtedly the extensive and widespread diabase dikes throughout Liberia. Petrographic examinations of many diabases show that ilmenite is the main opaque accessory mineral. Also, ilmenite is abundant in heavy mineral concentrates collected near diabase outcrops. Ilmenite is also the major accessory mineral in amphibolite and granulite in Liberia, but is only minor in granitic rocks. 
Zircon is derived mainly from the widespread granitic rocks in which it is a major accessory mineral. It is only a minor accessory in amphibolite.

Rutile is widespread in Liberia as fine grains, but coarse $(2-10 \mathrm{~mm})$ fragments have been found in unusually high concentrations in many stream samples from the Tawalata area (fig. 1, Mosaic Blocks H-12, H-13, I-12). Source rocks have not been identified, but the coarser rutile is probably derived from quartz veins; the finer grains are probably accessories in gneissic rocks. Promising high-grade deposits of rutile have been discovered along the Scarcies River in Sierra Leone, where a substantial tonnage of ore has been proved by Columbia-Southern Chemical Corporation and British Titan Products Ltd. (Lynd, 1960). Similar deposits also may be discovered in Liberia.

Magnetite is abundant in heavy mineral samples from the Wologizi area (fig. 1, Mosaic Blocks K-3, K-4, and K-5), and evidently is derived from the itabirite deposits in the area. Magnetite was also found in large quantities in many samples from Mosaic Blocks I-3 and J-3. However, it appears to have been derived from granitic rocks, where it occurs as an accessory mineral, and apparently is unrelated to any iron ore deposit.

Widely distributed monazite occurs as a minor accessory mineral of gneiss and schist derived from argillaceous sediments, and of granitic rocks that are so prevalent in Liberia. Monazite-rich rocks or "monazite ore" have not been identified. Samples of weathered gneiss and granitic rocks collected in place from the Voinjama-Kolahun area and concentrated in the laboratory show monazite contents ranging from a few tenths to a few hundredths of a percent. Such concentrations and presence of monazite in hundreds of heavy mineral samples indicate that monazite-placer deposits may exist in Liberia. An aeroradiometric survey has indicated several radioactivity anomalies that may reflect concentrations of monazite near Bopolu, the Voinjama-Kolahun area, and along some beaches between Robertsport and Greenville. High concentrations of monazite in beach sands at Greenville and Harper are associated with inland areas of high radioactivity east of these towns.

The aluminum silicates, sillimanite, kyanite, and staurolite, are most likely derived from metamorphosed pelitic rocks in the Cape Mount County area. Sillimanitebearing rocks, which are indicative of high-grade metamorphism including mediumgrained sillimanite schist and coarser quartz-sillimanite gneiss, have been mapped in the area. In addition, mica schists containing staurolite, almandine garnet, muscovite, kyanite, and quartz have been observed.

The source of corundum is still uncertain, as corundum-bearing rocks have not yet been observed in the field. Rounded fragments up to $15 \mathrm{~cm}$ long which have been found in stream gravels probably come from pegmatite or hydrothermal veins, or from a contact-metamorphic deposit where a basic or ultrabasic intrusive mass has desilicated an adjacent clayey sedimentary rock. Samples of corundum-spinel-diaspore fragments were found in stream gravels and as float in Mosaic Block E-16 (fig. 1); some metamorphosed basic igneous rocks are known in nearby areas. 
Alluvial gold occurs throughout Liberia. It is concentrated in the Bopolu and Voinjama districts of Lofa County and in the Bendaja district of Grand Cape Mount County (fig. 18). Placer gold mining by indigenous methods has been practiced in these areas for a long time (Sherman, unpublished report, 1942; Richards, unpublished report, 1954; Thayer, Lill and Coonrad, 1974). In 1957, however, gold mining was practically abandoned in favor of diamond mining, and little, if any, gold was produced thereafter.

During the 1966 field season, prospecting for gold was carried out by S. P. Srivastava and G. W. Leo in Mosaic Blocks E-14 and F-14 in Grand Cape Mount County where some mining was formerly done. Gold was obtained by panning anywhere in the known gold-bearing creeks such as Wueju, Weafua, Konja, and their tributaries, from the soil, and even from the weathered bedrock (Sherman, written commun., 1962; Leo, 1966; Thayer, Lill and Coonrad, 1974). Prospecting revealed that in addition to quartz veins, gold is disseminated in mafic, ultramafic, and granitic gneiss, and its distribution is apparently not controlled by lithology (Leo, 1966, p. 2). Thorough investigations of the gold-bearing areas is recommended to reveal the economic potential of the placer deposits and to throw some light on the source of the gold.

High concentrations of chromite in several heavy mineral samples from the Wologizi area most likely are derived from the nearby ultramafic rocks in the Wologizi Range. The largest area of ultramafic rocks is about $5 \mathrm{~km}$ long by $1.3 \mathrm{~km}$ wide and trends northeastward in Mosaic Block K-5, on the west side of the range. Further prospecting in the area is recommended.

The LAMCO report on exploration in the railroad concession area (Offerberg and Tremaine, 1961) indicated that resampling for tin was carried out in Mosaic Blocks M$20, \mathrm{~N}-19$, and $\mathrm{N}-20$. Cassiterite was identified as the tin mineral present and relatively high concentrations were found in some streams. It is believed that northeast-trending ridges that extend about 15-20 km through Mosaic Blocks M-19, M-20 and N-20 contain cassiterite-bearing pegmatites. More recent studies of this area by United National mineral survey team seem to confirm such a source.

\section{MINERAL PROVINCES}

Although more than 2,500 stream sand samples and beach concentrates have been studied, a clear picture of the sources of all 47 identified mineral species is not yet available. However, an attempt is made here to assemble the information according to the source of these minerals in order to assist in prospecting for minerals such as diamond, monazite, gold, rutile, and cassiterite. Some of the areas from which heavy mineral concentrates were collected (fig. 19), though disconnected and scattered, may be tentatively grouped into mineral provinces on the basis of unusual, distinctive, or predominant minerals or mineral assemblages (index minerals). Based on the index minerals, the following 5 provinces are shown in Figure 19. 


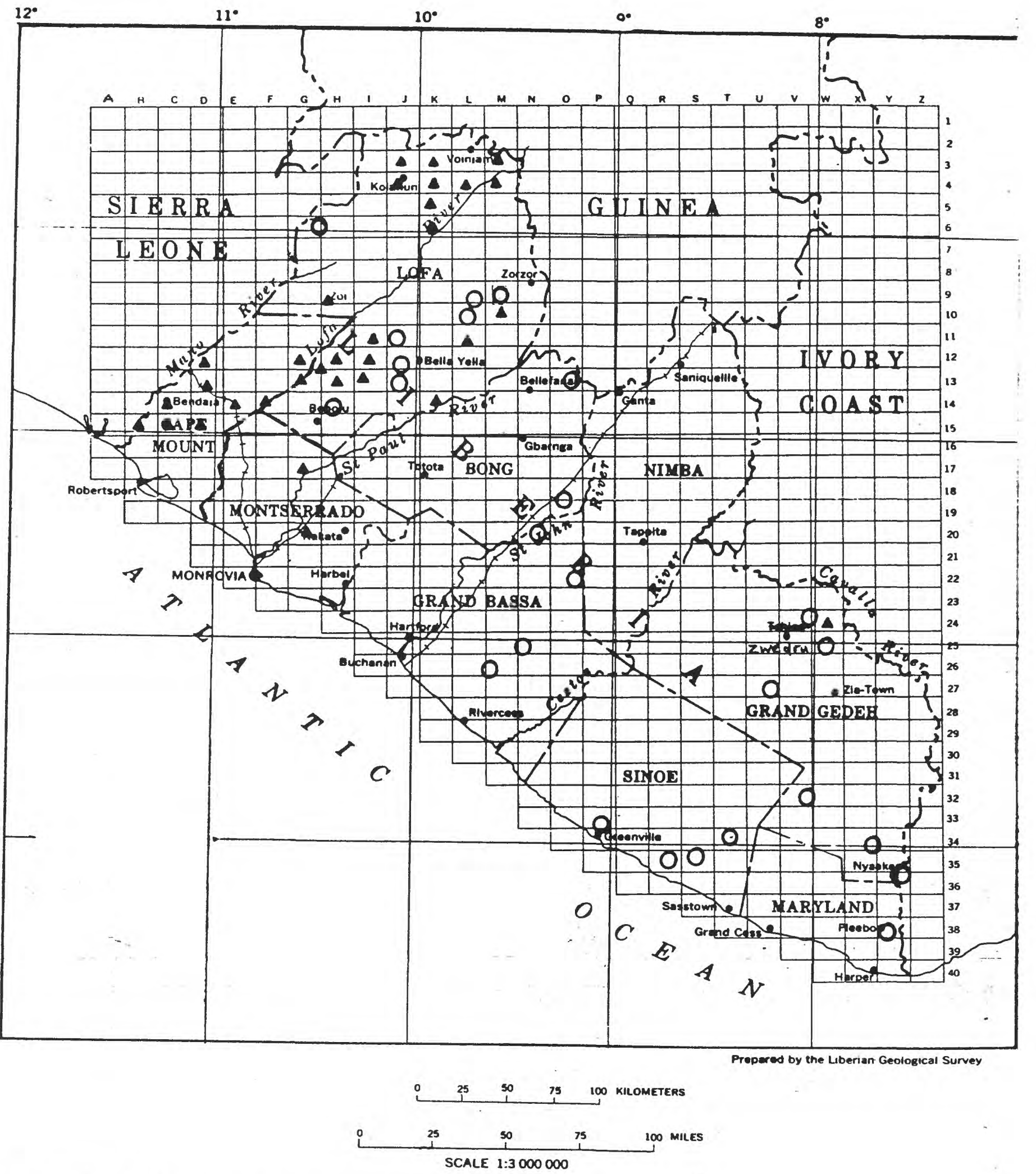

Figure 18. -Gold occurrences in Liberia

Key: - Occurrences confirmed by this study

Occurrences reported by reliable sources 

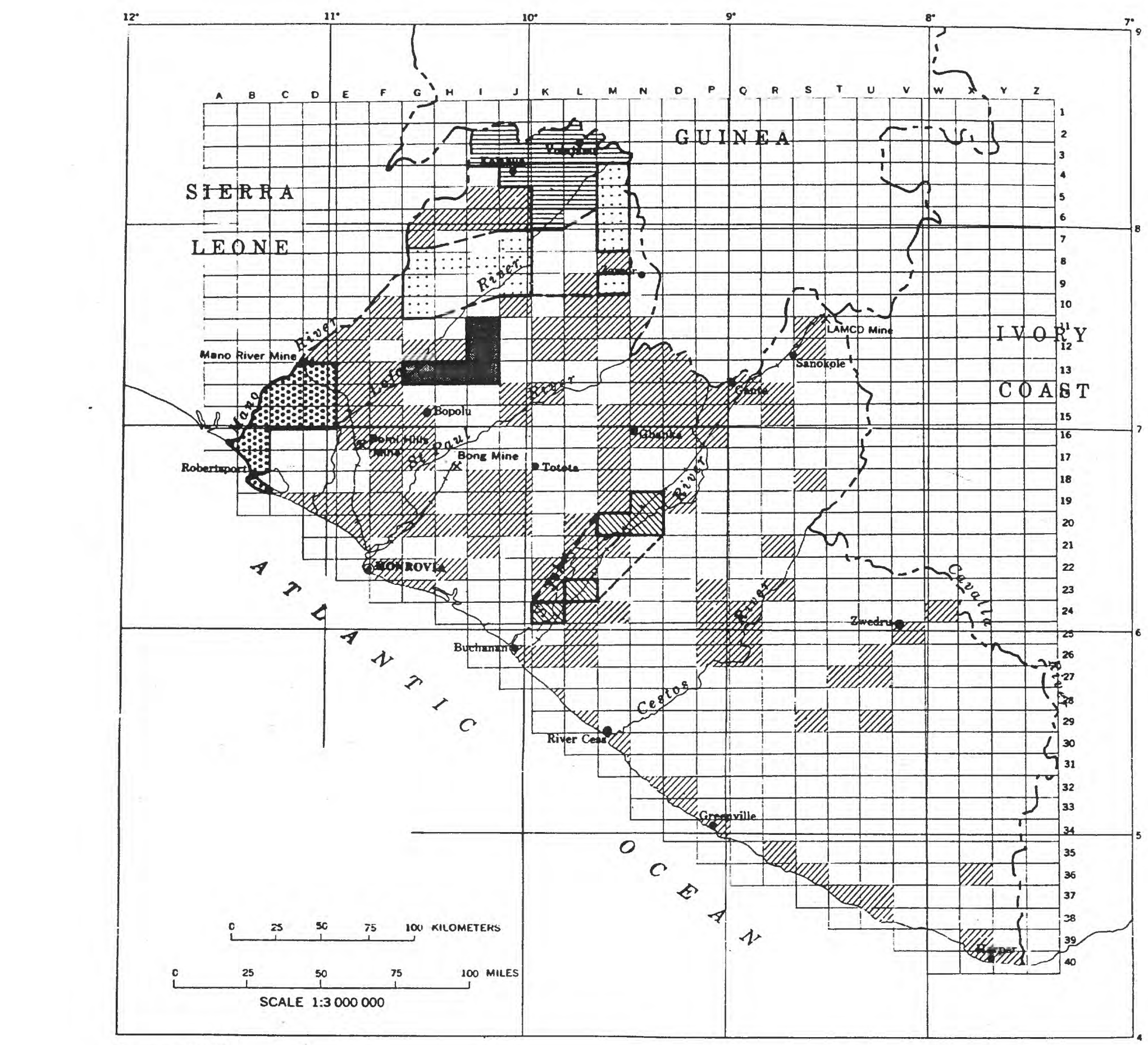

[1.0. Index minerals: sillimanite-kyanite-stourolite-corundum-monazite-gold

2 Index minerals: almandite-monazite-rutile-xenotime-corundum-gold

$\left.3^{\cdots:::}\right\}$ Index minerals: monazite

4 Index minerals: magnetite-monazite-chromite-hypersthene-xenotime-gold

5 IIIIIU Index minerals: cassiterite-columbite-tourmaline-almandite-staurolite-andalusite

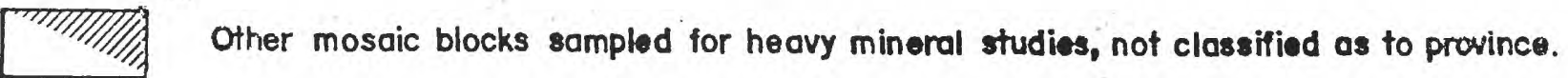

Figure 19 - Map showing areas sampled and approximate mineral provinces 
Province 1, the western area of Grand Cape Mount County near the Sierra Leone border. Aluminum silicate minerals (sillimanite, kyanite, and staurolite), corundum, monazite, and gold form a dominant mineral assemblage. (See figure 20a).

Province 2, the central part of the Lofa River basin in the Bopolu quadrangle, which is characterized by an almandite-monazite-rutile-xenotime-corundum-gold assemblage. (See figure 20b).

Province 3 , the northeastern part of the Bopolu quadrangle, where monazite is the dominant mineral in most samples and constitutes as much as 50 percent of some concentrates. Ilmenite and zircon, although abundant in all provinces, are higher than average (between 15 and 20 percent, each) in Province 3. (See figure 20c).

Province 4, the Voinjama-Kolahun area, in the northern part of Liberia, which is characterized by the magnetite-monazite-chromite-hypersthene-xenotine-gold assemblage. (See figure 20d).

Province 5, the St. John River area, is characterized by the presence of cassiterite. Most samples contain less than 1 percent cassiterite in the heavy-mineral fraction; the maximum is about 3 percent. Tourmaline, almandite, and staurolite are relatively abundant, and columbite and andalusite were recognized in some samples. (See figure 20e).

Zircon and ilmenite are so ubiquitously abundant that they are useless as index minerals to define a group. Rutile and monazite appear in practically all samples, but their relatively high abundances in Province 2 is sufficient to make them useful index minerals. Kyanite is considered an index mineral in Province 1 because of its relative abundance, and because it forms a distinctive assemblage with other aluminous minerals in the province. Cassiterite and columbite, though minor in abundance, are widespread enough in Province 5 to be considered index minerals. Hypersthene, a minor mineral, is designated an index mineral in Province 4. Xenotime occurs similarly in Province 2.

Confirmation of the foregoing index minerals is proven numerically by averaging the abundance values for each province. These averages are shown graphically in figures 20 a-e. Index minerals are indicated by solid bars.

\section{CONCLUSIONS}

The study of more than 2,500 samples from the areas shown in figure 19, allows only tentative conclusions concerning grades of metamorphism in Liberia and relations and commercial potential of some minerals. At present, the following conclusions may be drawn: 


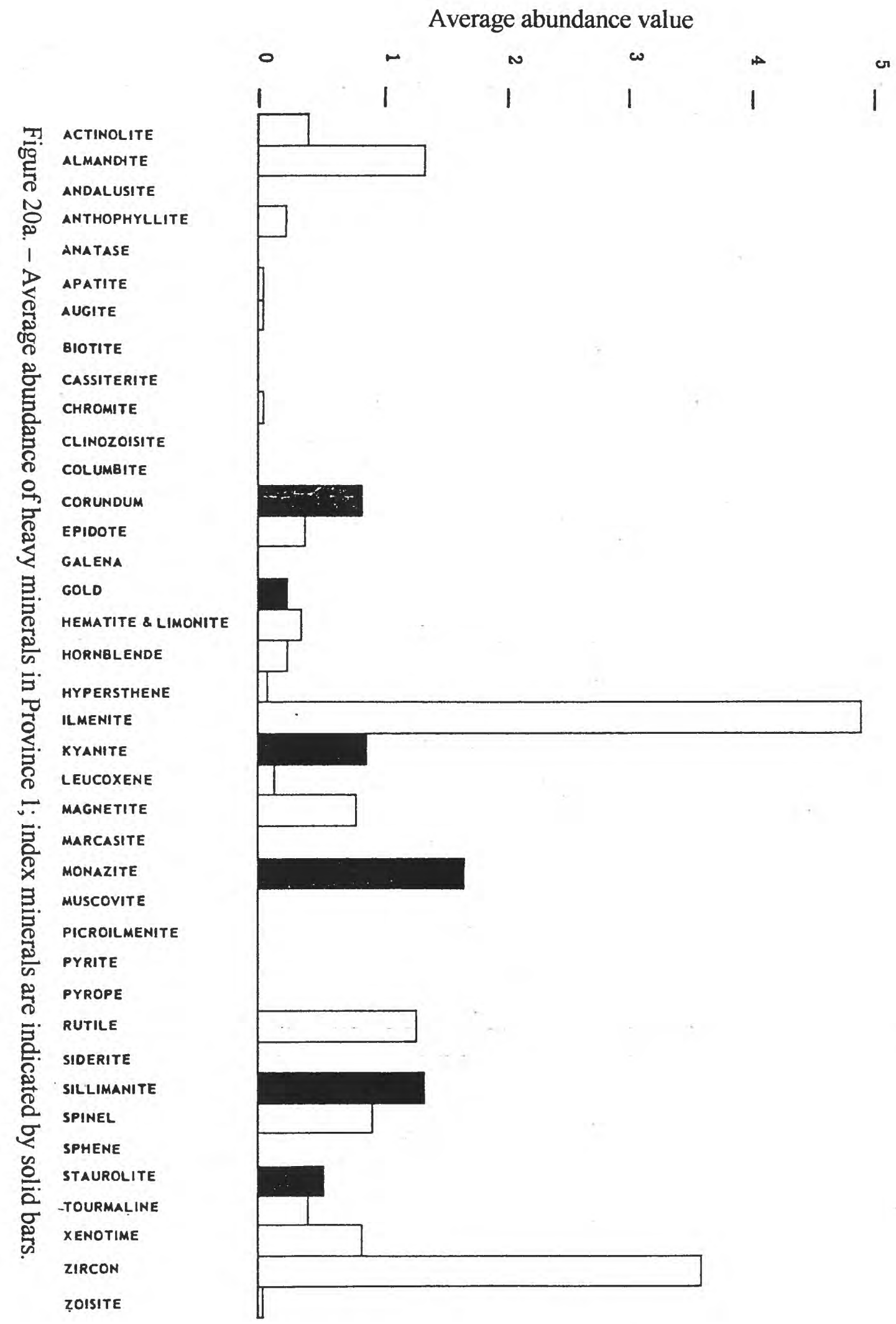




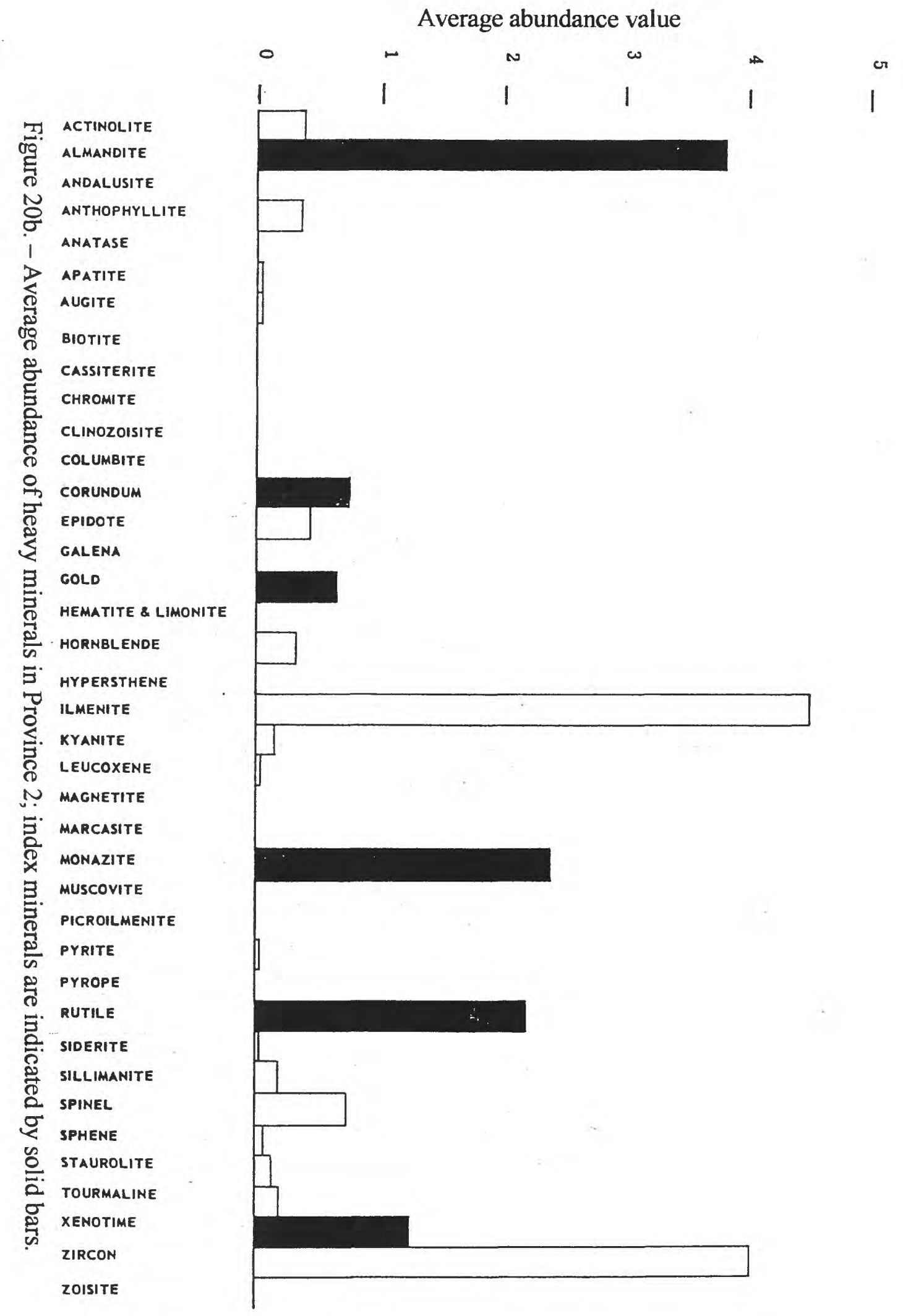




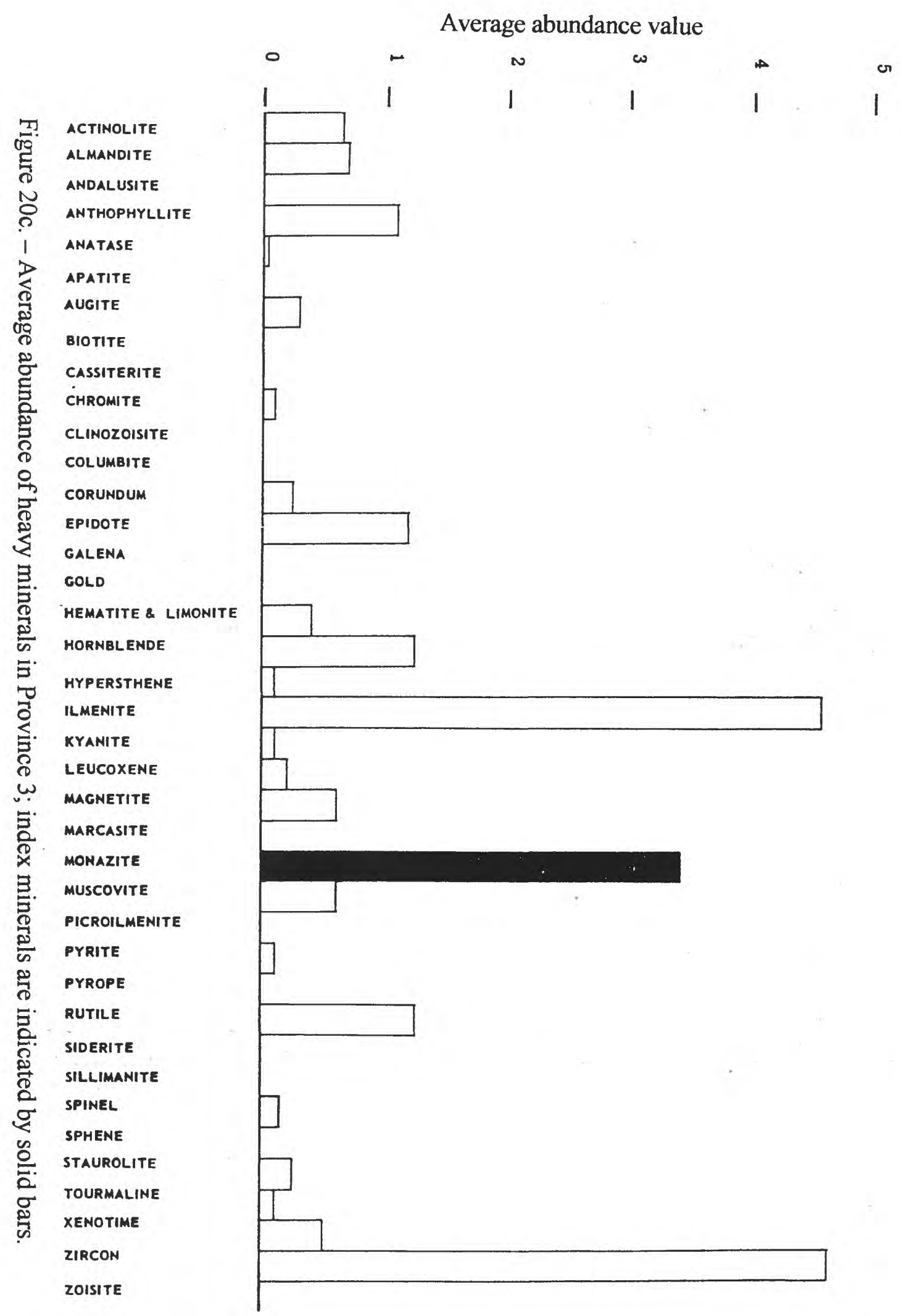




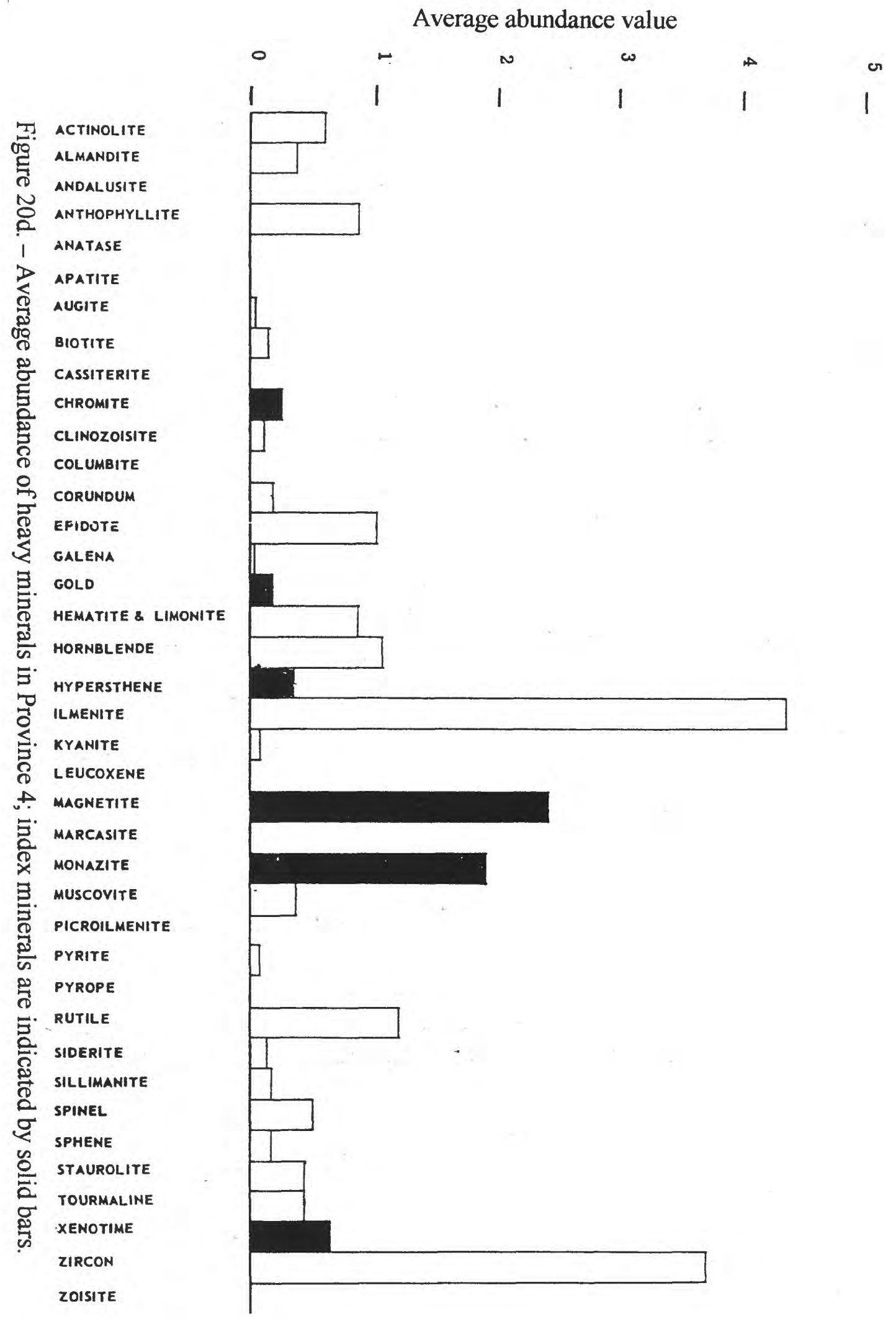




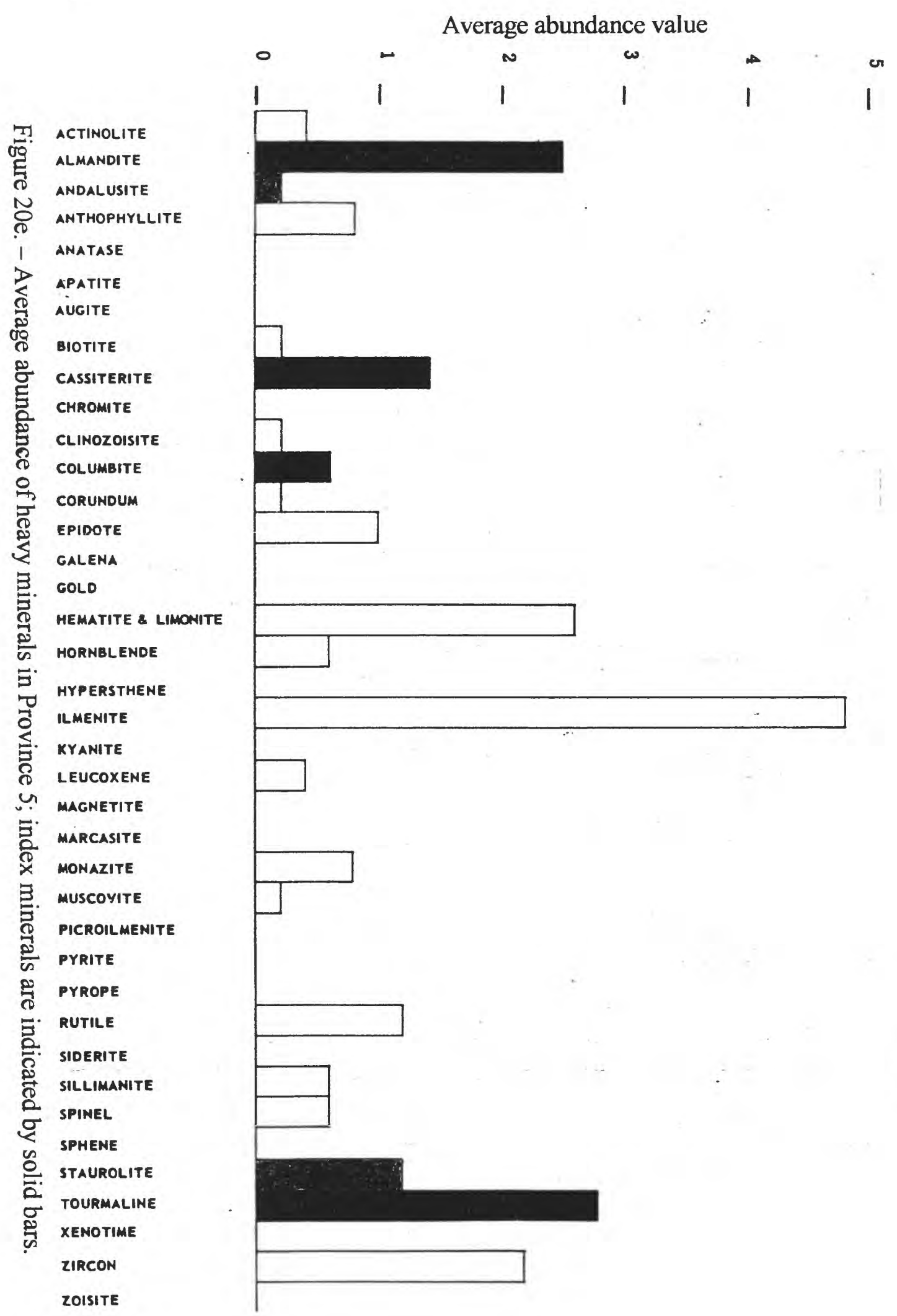


1. On the basis of relative abundances of the aluminous minerals, kyanite, sillimanite, and staurolite, and the ferromagnesian minerals, hypersthene, diopside, almandine, and hornblende, we can infer that the terrane in Liberia is in part composed of a metamorphosed volcanic-sedimentary sequence. Also, on the basis of relative abundances of the high-grade metamorphic facies minerals (orthopyroxene, clinopyroxene, kyanite, and sillimanite), we conclude that the grade of metamorphism affecting this sequence increases from central Liberia to eastern and western Liberia. Similar index minerals are either few or lacking in orthogneiss. Presumably the quartzofeldspathic gneiss was similarly subjected to the same metamorphic conditions, but lacking the index minerals, the present mode is to assign it to the amphibolite-facies grade. Where quartzo-feldspathic gneiss occurs within a mafic granulite zone (as in western Liberia) and exhibits pyroxene, it is referred to as felsic granulite.

2) Relatively abundant zircon and monazite are associated with areas of unusual aeroradioactivity, and apparently account for most of the radioactivity in the area. The zircons are generally dark in color, and some are metamict from radiation damage from the contained uranium.

3) Certain minerals, like siderite and marcasite, are diagenetically formed in place in the sample sites, as indicated by good crystal forms and relative chemical instability of the minerals in near-surface environments.

4) Unusually coarse grains of rutile (up to $2 \mathrm{~cm}$ ) and corundum (up to $15 \mathrm{~cm}$ ) found in the Tawalata area, about $35 \mathrm{~km}$ ( 20 miles) northeast of Bopolu, are most likely from contact metamorphic rocks. Gold, pyrite, and galena found in the same area are undoubtedly from veins. A sample of vein quartz from Mosaic Block F-13 (fig. 19) contained abundant sphalerite and minor galena.

5) Gold occurrences in a 15- to 20-mile-wide zone from Bendaja (Mosaic Block C-14), Grand Cape Mount County to Zorzor (N-9), Lofa County are not limited to any one lithologic unit, but the zone is generally parallel to the foliation of the gneissic terrane. Gold in quartz pebbles was found in Weaju Creek in Mosaic Block E-14, 24 miles due east of Bendaja. We suggest the gold is structurally controlled by quartz veins and is in different rock types along fractures that follow the foliation of the metamorphic rocks. Gold-quartz pebbles are found in central Liberia, near the St. John River, but not enough is known about this area to infer their origin and distribution.

6) It is noteworthy that diamonds were not recognized in any of the 100 to 200 heavy-mineral concentrates from the diamond-mining areas. This may be explained by: a) no diamonds less than 60 mesh are present; b) diamonds are so rare that even in 200 samples the probability is small that a diamond would be found; c) poor wetting of diamond (by water and heavy liquids) and surface tension phenomena may float small diamonds, which are inadvertently rejected with the light fractions. Inasmuch as kimberlitic ilmenite and garnet (pyrope) are recognized, diamonds should be present in the finer fractions. A better system of recovery should yield diamonds in the finer sizes and in sufficient quantity to be a source of income for the diamond mining industry. 
7) Except for beach deposits and local small diamantiferous and auriferous gravels, no placer deposits are extensive enough in the explored areas of Liberia to be worked for other valuable minerals. Beach sands in western Liberia, from Robertsport to Greenville, might be profitably worked to produce all of the following minerals provided there is a market: zircon, ilmenite, rutile, monazite, kyanite, sillimanite, magnetite, garnet, and a residue of silica sand. In the eastern beaches near Harper, sufficient shell fragments (about 60 percent) occur in the beach sand to be a possible source of calcium carbonate for a small cement or lime-products industry.

\section{REFERENCES}

Berman, Joseph, 1955, Identification of metamict minerals by X-ray diffraction: Amer. Mineralogist, v. 40 , nos. 9-10, p. 805-827.

Compton, R. R., 1962, Manual of field geology: John Wiley \& Sons, New York, p. 332333.

Deer, W. A., Howie, R. A., and Zussman, J., 1962, Rock-forming minerals: John Wiley \& Sons, New York, v. 1, 333 p.; v. 2, 379 p.; v. 3, 270 p.; v. 4, 435 p.; v. 5, 371p.

Feigl, F., 1958, Spot tests in inorganic analysis: Elsevier Publishing Co., New York, $600 \mathrm{p}$.

Flinter, B. H., 1959, Magnetic separation of some alluvial minerals in Malaya: Amer. Mineralogist, v. 44, p. 738-751.

Ford, W. E., 1932, Dana's textbook of mineralogy: John Wiley \& Sons, New York, $851 \mathrm{p}$.

Hess, H. H., 1956, Notes on operation of the Frantz isodynamic magnetic separator: S.G. Frantz \& Co., Trenton, New Jersey, 6 p.

Leo, G. W., 1966, Preliminary evaluation of gold-bearing rocks in Mosaic Block E-14: Liberian Geol. Survey Memo. $\quad$ Rept. 18, 3 p.

Leo, G. W., and Holmes, A. J., 1968, Evaluation of chromite content of some heavy mineral concentrates, Liberia: Liberian Geol. Survey, Memo Rept. 22, 6 p.

Leuria, Basil, 1966, Diamond prospecting in Lofa County: Geol. Mining Metall. Soc. Liberia Bull., v. 1, no. 1, p. 27-35.

Leuria, Basil, and Stracke, K. J., 1966, Diamonds and their occurrences in Liberia: Geol. Mining Metall. Soc. Liberia Bull., v. 1, no. 1, p. 5-12. 
Lynd, L. E., 1960, Titanium, in Industrial minerals and rocks, 3rd edition, (J.L. Gilson, ed.): Amer. Inst. Mining Engineers, Inc., New York, p. 851-880.

Meyer, H. O. A., 1968, Chrome pyrope; an inclusion in natural diamond: Science, v.160, p. 1446-1447.

Milner, H. B., 1962, Sedimentary petrography: George Allen \& Unwin., Ltd., London, v. 1,643 p.; vol. 2,715 p.

Muller, L. D. 1977, Laboratory methods of mineral separation, in Physical methods in determinative mineralogy, (J. Zussman, ed.): Academic Press, New York, p. 134.

Offerberg, Jan, and Tremaine, John, 1961, Report on LAMCO Joint Venture's geological investigations in Liberia between Nimba and Lower Buchanan along the railroad concession area: W-Reklam/Caslon Press Boktr. AB, Stockholm, 74 p.

Palache, C., Berman, H., and Frondel, C., 1944, The system of mineralogy, 7th ed: John Wiley and Sons, New York, v. 1, 834 p.; v. 2, 1134 p.; v. 3, 334 p.

Rosenblum, Sam, 1958, Magnetic susceptibilities of minerals in the Frantz Isodynamic Magnetic Separator: Amer. Mineralogist, v. 43, p. 170-173.

,1968, Chemical and spectrographic analyses of kyanite from Mount Montro, Grand Bassa County, Liberia: U.S. Geol. Survey Open-File Rept., 4 p.; Liberian Geol. Survey Memo. Rpt. 35, 4 p.

Roy, N. N., 1965, A modified spindle stage permitting the direct measurement of $2 \mathrm{~V}$ : Amer. Mineralogist, v. 50, p. 1441-1449.

Smith, O. C., 1953, Idenfication and qualitative analysis of minerals: D. Van Nostrand Co., Inc., New York, 38p.

Stanin, A. S., and Cooper, B. R., 1968, Mount Montro kyanite deposits, Grand Bassa County, Liberia: Liberian Geol. Survey Bull., no. 2, 20 p.

Stott-Cooper, H., 1967, Some notes on the damming operations carried out by the Liberian Swiss Mining Corporation on the Lofa River: Geol. Mining Metall. Soc. Liberia Bull., v 2, p. 9-16.

Thayer, T.P, Lill, G.G. and Coonrad, W.L., 1974, Mineral exploration in western Liberia, 1949-1950: Liberian Geological Survey Spec. Paper 4, 51 p.

Troger, W. E., 1952, Tabellen zur optischen bestimmung der gesteinsbildenden minerale: E. Schweizerbart'sche Verlagsbuchhandlung, Stuttgart, 147 p. 
Tysdal, R.G., and Thorman, C.H., 1983, Geologic map of Liberia: U.S Geol. Survey Miscellaneous Investigations Series, Map I-1480, Scale 1:1 million.

White, R.W., 1969, Sedimentary rocks of the coast of Liberia; U.S. Geol. Survey OpenFile Rept., 35 p., Liberian Geol. Survey Memo. Rept. 39, 35 p.

White R. W., and Leo, G. W., 1969, Geological reconnaissance in western Liberia: Liberian Geol. Survey Spec. Paper, no. 1, 18 p.

Wilcox, R. E., 1959, Use of the spindle stage for determination of principal indices of refraction of crystal fragments: Amer. Mineralogist, v. 44, p. 1272-1293. 1960, Optic angle determination on spindle stage: Geol. Soc. America Bull., v. 71, p. 2003.

Winchell, A. N., and Winchell, H., 1951, Elements of optical mineralogy, pt. 2: John Wiley \& Sons, New York, $551 \mathrm{p}$. 